Taxonomy of Thermopsis (Fabaceae) in North America

Author(s): Chia Jui Chen, Meghan G. Mendenhall and Billie L. Turner

Source: Annals of the Missouri Botanical Garden, Vol. 81, No. 4 (1994), pp. 714-742

Published by: Missouri Botanical Garden Press

Stable URL: http://www.jstor.org/stable/2399917

Accessed: 18-06-2015 19:07 UTC

Your use of the JSTOR archive indicates your acceptance of the Terms \& Conditions of Use, available at http://www.jstor.org/page/ info/about/policies/terms.jsp

JSTOR is a not-for-profit service that helps scholars, researchers, and students discover, use, and build upon a wide range of content in a trusted digital archive. We use information technology and tools to increase productivity and facilitate new forms of scholarship. For more information about JSTOR, please contact support @ jstor.org. 


\title{
TAXONOMY OF THERMOPSIS (FABACEAE) IN NORTH AMERICA $^{1}$
}

Chia Jui Chen, ${ }^{2}$ Meghan G. Mendenhall, ${ }^{3}$

and Billie L. Turner

\begin{abstract}
Comprehensive reevaluation of both herbarium specimens and field observations of the North American Thermopsis leads to our recognition of 10 species. Three species occur in the southern Appalachians: T. villosa, T. mollis, and T. fraxinifolia. The Rocky Mountains and intermountain regions are populated by the relatively variable and widespread species T. divaricarpa, T. montana, and T. rhombifolia. The Pacific coastal mountains of California are dominated by the variable $T$. californica (with three infraspecific taxa), which gives way to $T$. gracilis in northern California and western Oregon. Thermopsis macrophylla and T. robusta have restricted ranges in California.
\end{abstract}

Widely distributed throughout the western and southeastern United States, Thermopsis is a conspicuous, often weedy genus. Though it is a herbaceous plant, its relatively large habit and stunning racemes of golden or bright yellow flowers and flattened, rattling pods have no doubt contributed to its early and thorough collection. These factors, perhaps, should have led to a clear understanding of its systematics, but a lack of diagnostic characters within the genus, morphological intergradation, and possible hybridization have complicated the taxonomy of Thermopsis. Modern treatments (e.g., Isely, 1981) include from 4 to 10 species in North America, though over 20 specific names have been proposed.

The current study is based on over $20,000 \mathrm{~km}$ of roadside field study in North America (spanning 25 years for B. Turner), greenhouse studies (by M. Mendenhall), and the examination of approximately 6000 herbarium specimens (by all of the authors). We find 10 species of Thermopsis in North America. This treatment differs from earlier evaluations primarily in the rank and affiliations of taxa in the western United States. While an extreme perspective would combine the western taxa into two highly variable species, we recognize four species in the Pacific coastal states, three of which have restricted ranges, and three widely distributed species in the Rocky Mountain and intermountain regions. The three long-recognized species of the southeastern United States are maintained.

The following herbaria have generously supplied the approximately 6000 specimens used in this study (number of sheets loaned given in parentheses): ARIZ (113), CAS (516), COLO (181), F (193), GH (511), JEPS (16), LL (15), MO (444), MONTU (91), NCU (112), ND (99), NEBC (3), NY (715), ORE (78), OSC (85), PE (52), PH (193), POM (75), RM (611), RSA (302), TENN (71), TEX (163), UC (401), US (419), UT (83), WS (161), WTU (200).

\section{History OF THE Genus}

Thermopsis (Greek "thermos" = lupine + "opsis" = appearance) was originally included in Sophora by Linnaeus (1753). Willdenow (1799) placed the taxon in Podalyria. In 1811, Robert Brown erected Thermopsis based upon Sophora lupinoides L. Brown renamed the latter Thermopsis lanceolata, which is contrary to the present Code of Botanical Nomenclature (Greuter et al., 1988); the name Thermopsis lupinoides (L.) Link, erected in 1821 and recognized still, precludes the use of this specific epithet for the type species of the genus. In 1818, Nuttall called the genus Ther-

${ }^{1}$ This project was partially supported by the National Science Foundation of China and the May Scholar Fellowship at the Missouri Botanical Garden. This study was undertaken for the most part at the Plant Resources Center, Department of Botany, University of Texas at Austin. We are indebted to Peter H. Raven at the Missouri Botanical Garden for encouraging the senior author to undertake this study. We also thank Guy L. Nesom, Carol A. Todzia, and Steve Ginzbarg at the University of Texas at Austin, and Peter C. Hoch at the Missouri Botanical Garden for assistance in the preparation of the manuscript.

${ }^{2}$ Institute of Botany, Academia Sinica, Xiangshan, Beijing 100093, China.

${ }^{3}$ Author for correspondence, Department of Botany, University of Texas, Austin, Texas 78713, U.S.A.

${ }^{4}$ Plant Resources Center, Department of Botany, University of Texas, Austin, Texas 78713, U.S.A.

AnN. Missouri Bot. GaRd. 81: 714--742. 1994. 
mia. Rafinesque erected the genera Scolobus and Drepilia in 1819, both based on specimens of Thermopsis rhombifolia.

Larisey (1940) revised the North American Thermopsis because she saw considerable "taxonomic confusion," which she eventually ascribed to "bibliographical" problems. She distilled 22 published names to 10 species by reducing the 4 southeastern species to 3 and 18 western species to 7 . St. John (1941) responded to Larisey's revision with some notes on nomenclature and morphology. Though variously treated in regional floras, the most significant work on Thermopsis since its revision has been Isely's (1981) treatment in Leguminosae of the United States. Isely drastically reduced the number of species in Thermopsis, primarily by lowering these to varietal status. He perceived variation in the western taxa as too trivial to support the specific rank. Furthermore, he saw that "all taxa are seemingly confluent with those geographically contiguous." His views were not universally accepted at the time (Turner, 1982), and our findings support recognition of most of these taxa as separate species.

Thermopsis is the largest and most widespread member of the small tribe Thermopsideae, which consists of about 46 species in 6 genera (Turner, 1981). All of these are restricted to temperate regions of the Northern Hemisphere. The tribe is characterized by ten free stamens and petiolate, trifoliate leaves. Though most of the genera are woody, the two herbaceous genera, Baptisia and Thermopsis, account for most of the species in the Thermopsideae. These two genera are united by many other morphological as well as secondary chemical characteristics. In fact, Larisey (1940) referred to Thermopsis as a western geographical supplement of Baptisia, though it seems more likely that one or several lines of Baptisia was derived from a Thermopsis-like ancestor (Turner, 1967). In fact, Cranmer \& Turner (1967) offered Baptisia and Thermopsis as possible ancestors to the Genisteae on the basis of morphology, alkaloid chemistry, and geography. Since then, the woody Thermopsideae have been favored as close relatives to the Genisteae (Polhill, 1976; Turner, 1981).

\section{BIOGEOGRAPHY}

Thermopsis occurs not only in North America; 13 species are found in Asia. The Asian species occur at elevations of 1500-4000 m from India northward to eastern Kazakhstan and southern Russia, eastward across China, Mongolia, and Russia, and beyond to Japan, far eastern Russia, and the North American coast of the Bering Sea. Most of the Asian species were treated by Shishkin (1945). Judging from the relative uniformity of the North American species, taxa ancestral to extant Thermopsis probably crossed Beringia into North America.

On the North American continent, Thermopsis is distributed throughout the western states and in the southern Appalachian foothills. Thermopsis villosa and T. fraxinifolia are native to Tennessee, Georgia, and the Carolinas where they occur in woodlands at elevations of $700-1600 \mathrm{~m}$. Also in the east is $T$. mollis, which is found in the same states as $T$. villosa and $T$. fraxinifolia as well as in Virginia, but at lower elevations, typically between 300 and $800 \mathrm{~m}$.

In western North America, Thermopsis occurs both in the Rocky Mountain and intermountain regions as well as in the Pacific coastal states. Thermopsis montana is the most widely distributed species; it is found as two intergrading, regional varieties in the intermountain region from 300 to $3200 \mathrm{~m}$. Morphology and habitat are variable throughout its range from Montana southward to Arizona and New Mexico and northwestward to Wyoming, Idaho, Oregon, and Washington. Found at relatively low elevations, $1000-2000 \mathrm{~m}$, is $T$. rhombifolia. Although this taxon can be found from Alberta and Saskatchewan to New Mexico, it is largely restricted to alluvial soils in dry grasslands. Thermopsis divaricarpa occurs at middle to high elevations, 2000-3000 m, in the Rocky Mountains from Wyoming to New Mexico, in mesophytic conifer forests.

Most of the Thermopsis in the Pacific coastal states is found in California. In central California, T. californica var. californica is common in chaparral west of the Sierra Nevadas up to $1000 \mathrm{~m}$ elevation. In northwestern California and southern Oregon, T. gracilis is dominant and occurs at low elevations, to $1200 \mathrm{~m}$, in mesophytic forests. The remaining taxa in the extreme west have restricted distributions within California. Thermopsis californica var. argentata has a disjunct range in northeasternmost and southwestern California; this taxon grows at high elevations, 1200-2200 $\mathrm{m}$, in montane chaparral and pine forests. Thermopsis macrophylla is known only from the western side of Santa Ynez Peak in Santa Barbara County. Our study of type material indicates that this name has been erroneously applied to the more common $T$. californica var. californica. Unlike the latter, $T$. macrophylla is highly localized, relatively uniform, and strikingly robust. Equally impressive in habit is Thermopsis robusta, which is found only in 
TABLE 1. Chromosome numbers in Thermopsis. Counts listed with voucher only are original meiotic counts by the junior author $(\mathrm{T})$; vouchers on deposit at TEX.

\begin{tabular}{|c|c|c|}
\hline & $2 n$ number & Reference/voucher \\
\hline \multicolumn{3}{|l|}{ Asian species } \\
\hline T. alterniflora Regel & 18 & Federov (1969) \\
\hline T. barbata Benth. ex Royle & 18 & Chen et al. (1992) \\
\hline T. chinensis Benth. ex S. Moore & 18 & Yeh et al. (1986) \\
\hline T. chinensis Benth. ex S. Moore & 18 & Chen et al. (1992) \\
\hline T. lanceolata $\mathrm{R} . \mathrm{Br}$. & 18 & Mesicek \& Sojak (1969) \\
\hline T. lanceolata $\mathrm{R} . \mathrm{Br}$. & 18 & Chen et al. (1992) \\
\hline T. licentiana E. Peter & 18 & Chen et al. (1992) \\
\hline \multicolumn{3}{|c|}{ T. lupinoides (L.) Link [as T. fabacea } \\
\hline (Pallas) DC.] & 18 & Federov (1969) \\
\hline T. lupinoides (L.) Link & 18 & Probatova \& Sokolovskaya (1981) \\
\hline T. mongolica Czefr. & 18 & Mesicek \& Sojak (1969) \\
\hline T. przewalskii Czefr. & 18 & Chen et al. (1992) \\
\hline \multicolumn{3}{|l|}{ American species } \\
\hline T. californica var. argentata & 18 & California: Modoc Co., T. 5813, T. 5816 \\
\hline T. divaricarpa & 36 & Colorado: Jefferson Co., T. 5636 \\
\hline T. divaricarpa & 36 & Colorado: Las Animas Co., T. 5772 \\
\hline T. divaricarpa & 36 & Colorado: Saguache Co., Tomb 649 \\
\hline T. gracilis & 36 & Oregon: Lane Co., T. 5797 \\
\hline T. macrophylla & 18 & California: Santa Barbara Co., T. 5820 \\
\hline T. montana (var. montana?) & 18 & Federov (1969) \\
\hline T. montana (var. montana?) & 18 & Colorado: Summit Co., Gillett (1975) \\
\hline T. montana var. montana & 18 & Colorado: Saguache Co., T. 5775 \\
\hline T. montana var. montana & 18 & Idaho: Owyhee Co., T. 5798 \\
\hline T. montana var. montana & 18 & Nevada: Elko Co., T. 5795, T. 5796 \\
\hline T. montana var. montana & 18 & Utah: Wasatch Co., T. 5794 \\
\hline T. rhombifolia & 18 & CANADA: Saskatchewan, Ledingham (1957) \\
\hline T. rhombifolia & 18 & CANADA: Saskatchewan, Taylor (1967) \\
\hline T. rhombifolia & 18 & CANADA: Saskatchewan, Federov (1969) \\
\hline T. rhombifolia & 18 & CANADA: Manitoba, Löve \& Löve (1982) \\
\hline T. rhombifolia & 18 & Colorado: Huerfano Co., T. 5773 \\
\hline T. villosa & 18 & Zhukova (1967) \\
\hline
\end{tabular}

Humboldt and Siskyou Counties of northwestern California along ridgetops to $1500 \mathrm{~m}$. Finally, Thermopsis californica var. semota is restricted to the woodlands of San Diego County.

\section{Chromosome Numbers}

The first chromosome counts for Thermopsis were obtained by Russian workers in 1931 (Federov, 1969). These were obtained for the Asian species, T. alterniflora, and the American species, T. montana; both were found to have somatic counts of $2 n=18$. Subsequent counts for all of the species investigated have also been on a base of $x=9$ (Table 1).

Polyploids $(2 n=36)$ are known in only two species, T. gracilis and T. divaricarpa, both American, the former occurring in northern California and adjacent Oregon, the latter occurring in the front range of the Rocky Mountains, mostly in central Colorado. Polyploidy is believed to have arisen independently in the two taxa, largely because of their geographical isolation from one another. Relatively few counts have been recorded for these two taxa, however, and it remains to be seen if such counts will hold throughout their respective distributions.

A base chromosome number of $x=9$ is also found in the closely related Baptisia, a genus of about 17 species that is confined to lower elevations of the southeastern United States (see Isely, 1981, for overview). To date, no polyploids have been reported for Baptisia.

\section{Secondary Chemistry (Micromolecules)}

Unlike in Baptisia, flavonoids and alkaloids have been of limited usefulness in characterizing interspecific variation in Thermopsis. On the basis of quinolizidine alkaloid distribution, Salatino \& Gott- 
lieb (1980) were able to divide Thermopsis into two phyletic groups, the Asian and the North American species. A comprehensive phylogeny, however, has not yet been proposed since alkaloid and flavonoid data are insufficient (Turner, 1967; Dement \& Mabry, 1975) and contradictory (Balandrin et al., 1982).

Secondary chemical data have been used, nonetheless, to place the genus within a phylogenetic reconstruction of a larger scale. Based on quinolizidine alkaloid distributions (Salatino \& Gottlieb, 1980), most of the Thermopsideae probably arose from "Sophora-like taxa" (Turner, 1981). Furthermore, based on serological cross reactivity of seed proteins (Cristofolini, 1987), general morphology (Polhill, 1976), and phytochemistry (Faugeras \& Paris, 1968; Harborne, 1969; Salatino $\&$ Gottlieb, 1983), the woody Thermopsideae gave rise in turn to the Genisteae (Bisby, 1981; Cristofolini \& Feoli-Chiapella, 1984; Polhill, 1976; Turner, 1981).

\section{MORPHOLOGY}

Thermopsis has been commonly referred to as "false lupine," "buckbean," "goldenpea," "golden banner," and "bush pea." Though the flower has inspired several of these names, it varies little within the genus and is not especially useful for specific delimitation. There are slight variations in flower size and petal shape, which often appear constant within a taxon, but these are so minor as to be of limited usefulness for identification purposes.

Fruit characters are used to distinguish between Thermopsis and Baptisia; compressed pods are mostly found in the former and inflated in the latter. The posture and shape of the mature pods vary diagnostically within Thermopsis as well. The fruit may be erect, ascending, or divergent from the raceme axis. There seems to be no geographical correlation to pod posture; T. californica and $T$. macrophylla of California, T. montana of the intermountain region, and T. villosa of the Appalachians all have erect or ascending fruits, and irregularly to strongly divergent pods are found in the remaining species. Likewise, pod shape varies among species of the same region, though pods that are strongly divergent will also be arcuate or annular. Isely (1981) noted that ovule number is characteristic within regions of the generic distribution. Indeed, we found that in southern California Thermopsis typically has 5-9 ovules and in northern California 8-14 ovules. The Rocky Mountain and intermountain species have 10-18 ovules and the Appalachian species have 12-16. These figures do overlap, however, and can be called trends at best.

Vegetative characters are often quantitative with much variation around average proportions. Nevertheless, certain characters have wide diagnostic application within the genus. Plant height, leaf size and shape, and pubescence have some utility, though there is overlap between taxa, especially varieties. Although the leaf apices may differ on a single plant, the number of leaf veins and their visibility are sometimes useful. The stipules are of two types: the lower stipules in all taxa are scarious and do not subtend leaves, the upper are foliaceous and blade-bearing. The foliaceous stipules differ diagnostically in shape, ranging from lanceolate to broadly ovate, and in size, growing to $9 \mathrm{~cm}$ long and $6 \mathrm{~cm}$ wide. Inflorescence bracts, likewise, vary in shape and size and also in persistence. Racemes may bear short or long pedicels, and these may be pubescent or not. In addition, the flowers may be scattered along the axis or may be inserted in whorls, even where the flowers are not especially dense. Within the flowers, calyx proportions may confirm identity but are not especially useful alone.

Most Thermopsis species propagate by rhizomes, sometimes, as in T. mollis and T. rhombifolia, forming extensive clonal populations. Otherwise, the plants are supported by thick, perennial rootstocks. It is often impossible to confirm the presence of rhizomes on herbarium specimens, especially of large plants, which typically show just enough of the apical structures to fit on a herbarium sheet. Yet field observations indicate that a given taxon will have a tendency to form rhizomes or not, and this character should be preserved during collection and noted for identification.

For stems, branches, and fruits, the angle of insertion is described as erect, ascending, divergent, or spreading. Distinctions between these terms may be confusing. In the following descriptions, "erect" indicates vertical posture or nearly so and little or no curvature at the point of attachment while "ascending" indicates an angle of attachment up to $50^{\circ}$ from vertical often with upward curvature at the point of attachment. Though "spreading" and "divergent" are roughly synonymous, here "spreading" is used for branches and "divergent" is used for fruits.

\section{SPECIES AND Varietal ConcePtS}

As is discussed above, the primary difference in the various treatments of Thermopsis has been in the rank of the taxa. In this treatment, the specific rank has been chosen to express what we perceive 
to be evolutionarily independent taxa. We have inferred this from morphological evidence of reproductive independence both from herbarium specimens and observations of populations in the field. For example, although occasional sympatric hybridization is suspected between members of $T$. divaricarpa and both T. montana and T. rhombifolia, there is no evidence that these hybrids have stabilized and persisted. Nevertheless, Isely occasionally, if not often, saw intergradation, where we, like Larisey, see none. We attribute the resolution of our perception to the extensive field and herbarium work that is the basis of this study.

\section{Taxonomic Treatment}

Thermopsis R. Br., Hortus Kew., ed. 2, III. 3. 1811. TYPE: Sophora lupinoides L. = Thermopsis lanceolata $\mathrm{R} . \mathrm{Br} .=$ Thermopsis lupinoides (L.) Link.

Thermia Nutt., Gen. N. Amer. Pl. 1: 282. 1818. TYPE: Thermia rhombifolia (Pursh) Nutt.

Scolobus Raf., Amer. Monthly Mag. Crit. Rev. 4: 193. 1819. TYPE: Scolobus rhombifolius (Nutt. ex Pursh) Raf.

Drepilia Raf., N. Fl. 2: 52.1836 [1837]. TYPE: Drepilia rhombifolia (Nutt. ex Pursh) Raf.

Perennial herbs, usually rhizomatous; stems erect or ascending, few-branched to well-branched, branches ascending or spreading; plants glabrate to variously pubescent, unarmed. Leaves petiolate, trifoliolate, not glandular-punctate; stipules usually persistent, foliaceous or nearly so, dimorphic, the lowermost amplexicaul, scarious, and not bladebearing, the rest broadly ovate to lanceolate and subtending leaves, to $6(-9) \mathrm{cm}$ long, to $3(-6) \mathrm{cm}$ wide, smaller and narrower on branches; leaflets subpetiolulate, narrowly elliptic to obovate, 2$8(-10) \mathrm{cm}$ long, margins entire; estipellate. Inflorescences terminal (lateral) racemes, commonly solitary, flowers few to numerous, scattered or whorled; bracts deciduous or persistent, widely ovate to lanceolate, acute to acuminate; bracteoles ab- sent; pedicels 2-17 mm long. Flowers papilionaceous; calyx campanulate, appearing 4-lobed, subequal, the upper lobe double, broader, and slightly longer than the others, truncate to emarginate, the lower lobes deltoid to lanceolate; corolla yellow; banner very widely ovate, shorter than wings and keel, cleft (emarginate and short mucronate), claw cuneate to oblong, replicate-reflexed; wings usually asymmetric, elliptic to oblong-rhombic, auriculate, \pm length of keel, not adnate to keel, claw narrowly oblong; keel asymmetrically oblong-elliptic to carinate, auriculate, posteriorly fused, without a beak, claw narrowly oblong; stamens 10, free, uniform; anthers dorsifixed; pistil short-stipitate; ovary oblong, usually longer than style, villosulous; ovules 5-15; style glabrous; stigma minute. Legumes persistent, erect, ascending, or divergent, tan to brown, narrowly elliptic, laterally compressed, straight, arcuate, or rarely annular, margins straight or, as a consequence of ovule abortion, sinuate or lomentaceous; pericarp chartaceous, not elastic, variously pubescent; stipe $2-4 \mathrm{~mm}$ long; fruits slowly dehiscent, valves separating from apex through both sutures. Seeds (1-)3-10 per fruit, tan to brown-black, oblong to reniform, often with a minute, membranaceous rim-aril. Base chromosome number, $x=9$.

Diagnosis and relationships. Thermopsis is a member of the Thermopsideae Yakovlev (Bot. Žurn. 57: 585-595, 1972), by virtue of its free stamens and palmately trifoliate, petiolate leaves. Although Thermopsis is loosely allied with all other Thermopsideae, it is very similar morphologically to Baptisia, the other prominent North American member of the tribe. Fruiting Thermopsis can be distinguished readily from Baptisia. The pods of North American Thermopsis are flattened, while those of Baptisia are inflated.

As detailed above, Thermopsis is found in Asia and North America. In North America four species occur in the Pacific coastal states, three occur in the Rocky Mountains and intermountain regions, and three are found in the southern Appalachians.

\section{Key to SPECIES}

la. Plants of southern Appalachian foothills.

2a. Stipules on primary axis more than $1 \mathrm{~cm}$ wide; pedicels less than $3 \mathrm{~mm}$ long; pods erect, densely villous ................................................................................................. The villosa

2b. Stipules on primary axis less than $1 \mathrm{~cm}$ wide; pedicels more than $3 \mathrm{~mm}$ long; pods irregularly divergent, pubescent or glabrate.

3a. Plants rhizomatous; pedicels villosulous and shorter than bracts; racemes terminal; mostly piedmont, 300-800 m 6. Thermopsis mollis

3b. Plants from a single woody rootstock; pedicels glabrate and at least as long as bracts; racemes terminal or lateral; montane, usually $1000-2000 \mathrm{~m}$

3. Thermopsis fraxinifolia

lb. Plants of Rocky Mountains, intermountain regions, and Pacific coastal states.

4a. Plants tomentose or sericeous throughout; flowers usually in whorls of 3-5; California. 
5a. Plants mostly 3-8 dm tall; leaflets mostly 3-7 cm long; pods ascending, usually with several or more abortive ovules

5b. Plants mostly 10-20 dm tall; leaflets up to $11 \mathrm{~cm}$ long; pods ascending or divergent, usually with well-developed ovules.

6a. Pods ascending and straight; pedicels $2.5-4 \mathrm{~mm}$ long; lateral leaf veins 6-8 pairs; Santa

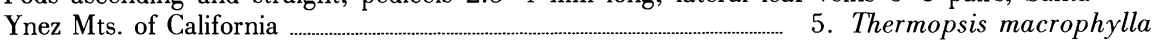

6b. Pods divergent and arcuate; pedicels $4-8 \mathrm{~mm}$ long; lateral leaf veins 9-12 pairs; Humboldt and Siskiyou Counties of northwestern California …_............... 9. Thermopsis robusta

4b. Plants glabrate to pubescent; flowers usually scattered; Pacific coastal mountains north of $40^{\circ} \mathrm{N}$ latitude, and more central portions of the western United States and adjacent Canada.

7a. Pods erect and straight

7b. Pods divergent and straight, arcuate, or annular.

8a. Branches spreading, strongly zigzagged; leaflets more than $2 \mathrm{~cm}$ wide, sometimes emarginate; petioles more than $2.5 \mathrm{~cm}$ long; pods straight; western Oregon and northern California

4. Thermopsis gracilis

8b. Branches ascending, weakly to moderately zigzagged; leaflets less than $2 \mathrm{~cm}$ wide, not emarginate; petioles less than $2.5 \mathrm{~cm}$ long; pods usually arcuate or annular; northern and eastern Rocky Mountains and adjacent Great Plains.

9a. Plants 3-9 dm tall; leaflets more than $3 \mathrm{~cm}$ long, lateral veins 7-10 pairs; stipules ovate to narrowly elliptic; flowers $2.5-3.0 \mathrm{~cm}$ long; pods straight to arcuate

2. Thermopsis divaricarpa

9b. Plants mostly $1-3 \mathrm{dm}$ tall; leaflets less than $3 \mathrm{~cm}$ long, lateral veins $5-7$ pairs; stipules usually widely ovate; flowers $1.6-2.1 \mathrm{~cm}$ long; pods strongly arcuate to annular

8. Thermopsis rhombifolia

1. Thermopsis californica S. Watson, Proc. Amer. Acad. Arts 11: 126. 1876. TYPE: U.S.A. California: Marin Co., Corte Madera, J. M. Bigelow 1854 (lectotype, selected here, NY; probable isolectotypes, NY, PH, US).

Plants robust, (2.5)3-8 dm tall, sericeous or tomentose; stems slender, erect, clustered, wellbranched, arising from rhizomes; branches ascending at $20-45^{\circ}$, weakly to strongly zigzagged. Leaflets elliptic or obovate, 3-7(-9) cm long, 1.2$4(-4.5) \mathrm{cm}$ wide, obtuse or acute, silvery sericeous or tomentose to villous, lateral veins 6-9 pairs, conspicuously net-veined beneath; petioles $1-3.5$ cm long; stipules persistent, widely ovate to lanceolate, $1.5-6.5 \mathrm{~cm}$ long, $0.7-5 \mathrm{~cm}$ wide, cuneate to amplexicaul, acuminate. Racemes $7-30(-35)$ cm long, with 10-40 flowers usually in whorls of 3-5; peduncles (2-)4-10 cm long; pedicels 2-6 $\mathrm{mm}$ long, sericeous or tomentose; bracts semipersistent, ovate to lanceolate, 6-15 mm long, 2.5$15(-20) \mathrm{mm}$ wide. Flowers $1.5-2.0 \mathrm{~cm}$ long; calyx 5-10 mm long, 5-9 $\mathrm{mm}$ wide at the limb, lobes 2.5-5 $\mathrm{mm}$ long, as long or longer than tube; wing and keel petals oblong-elliptic to nearly reniform; ovary velutinous; ovules 5-11. Pods straight, ascending (irregularly divergent when young), 2$6(-7) \mathrm{cm}$ long, (0.5-)0.6-0.9 cm wide, sericeous, tomentose, or velutinous. Seeds $1-6(-10)$, oblong with a short rostrum, $4-5.5 \mathrm{~mm}$ long, $2.5-4 \mathrm{~mm}$ wide.

Three varieties are recognized within Thermopsis californica as follows:

\section{KeY to VARIETIES OF THERMOPSIS CALIFORNICA}

la. Stipules widely ovate to ovate, to $5.0 \mathrm{~cm}$ wide; bracts to $15 \mathrm{~mm}$ wide; peduncles usually more than $6 \mathrm{~cm}$ long; pod pubescence of matted trichomes

1b. Thermopsis californica var. californica

lb. Stipules ovate to lanceolate, to $2.5 \mathrm{~cm}$ wide; bracts to $6 \mathrm{~mm}$ wide; peduncles usually less than $6 \mathrm{~mm}$ long; pod pubescence of straight, appressed trichomes.

2a. Silvery sericeous throughout; wing and keel petals reniform; northeastern and southwestern California

... la. Thermopsis californica var. argentata

$2 \mathrm{~b}$. Villous to densely tomentose; wing and keel petals oblong-elliptic; restricted to San Diego Co., California

.......... lc. Thermopsis californica var. semota

1a. Thermopsis californica var. argentata (E. Greene) C. J. Chen \& B. Turner, comb. nov. Basionym: Thermopsis argentata E. Greene, Erythea 3: 18. 1895. Thermopsis gracilis var. argentata (E. Greene) Jepson, Man. Fl. Pl. Calif. 515. 1925. Thermopsis macrophylla var. argentata (E. Greene) Jepson, Man. Fl. Pl. Calif. 2: 245. 1936. TYPE: U.S.A. California: Modoc Co., "Forestdale," Baker 1893 (lectotype, selected here, ND; isolectotypes, CAS, ND, NY, US).

In his protologue Greene cited a single collection from Modoc County, without locality, made by Milo S. Baker in 1893. Examination of material at ND reveals two sheets collected by Baker in the "Big Valley Mts." during June-August 1893. Both 
sheets, which bear printed labels, were subsequently modified by hand-inkings so as to read August 1894. One sheet is clearly a mixture of plants collected in June (flowering sprig) and fall (late fruiting sprig). The other sheet is in late fruit. We have designated the latter as lectotype.

Plants (2.5-)3-5 dm tall, silvery sericeous throughout; branches weakly to moderately zigzagged. Leaflets obovate to elliptic, $3-6.5 \mathrm{~cm}$ long, $1.2-3.5 \mathrm{~cm}$ wide, obtuse to acute sometimes with a short mucro; petioles $1.3-2.1 \mathrm{~cm}$ long; stipules lanceolate to ovate, $1.5-6.0 \mathrm{~cm}$ long, $0.8-2.5 \mathrm{~cm}$ wide, cuneate to cordate. Racemes $8-20(-25) \mathrm{cm}$ long, with 10-30 flowers; peduncles $4-7(-10) \mathrm{cm}$ long; bracts ovate to lanceolate, $7-15 \mathrm{~mm}$ long, 2.5-5 mm wide. Calyx 7-9(-10) mm long, 5-8 $\mathrm{mm}$ wide at the limb, lobes 3.5-4.5(-5) mm long; banner cleft; wing and keel petals asymmetrically oblong-elliptic to reniform; ovules 8-11. Pods 36(-7) cm long, (0.5-)0.7-0.9 cm wide. Seeds 16, oblong, 4-5(-5.5) mm long, (2.5-)3.5-4 mm wide. Chromosome number, $2 n=18$.

Distribution and ecology (Fig. 1). Northeasternmost California (southeastern Siskiyou Co. and closely adjacent Shasta, Modoc, and Lassen cos.) and again in southwestern California (Kern, Ventura, Santa Barbara, and Los Angeles cos.), mostly interior montane chaparral and pine forests from 1200 to $2200 \mathrm{~m}$; flowering May-June.

Representative specimens examined. U.S.A. California: Kern Co., Mt. Pinos, June 1905, Hall 6378 (UC); Owens Valley and at Fort Tejon, Horn 1863 (NY). Lassen Co., ridge $\mathrm{W}$ of Nubieber, along California Hwy. 299, 26 June 1941, Heller 16229 (MO, NY, WTU). Los Angeles Co., Santa Barbara, Liebre Ridge, N slope Liebre Mt., 15 Oct. 1923, Hunt 5 (CAS, RM). Modoc Co., Forestdale, Baker 1894 (NY, PH, POM, RM, US); Forestdale, Baker 1899 (PH, UC); Forestdale, Baker \& Nutting 1894 (CAS, GH, NY, RM, UC); $3 \mathrm{mi}$. NW of Lookout, 3 June 1968, Turner 5813 (TEX); 14 mi. NW of Lookout, 3 June 1968, Turner 5816 (TEX). Santa Barbara Co., San Rafael Mt., Ford 1887 (GH); Santa Ynez, Big Pine Mt., 7 Aug. 1936, Peterson 303 (UC). Shasta Co., ca. $20 \mathrm{mi}$. W of Fall River Mills, 24 May 1940, Hitchcock 6533 (NY, POM, UC, WTU); $1 \mathrm{mi}$. W of Dana, 2 June 1968, Turner 5809 (TEX). Siskiyou Co., just E of Barnum Flat Reservoir, 3 June 1968, Turner 5817 (TEX). Ventura Co., Fort Tejon, 19 June 1935, Axelrod 434 (POM, UC); Mt. Pinos region, 28 June 1896, Dudley \& Lamb 4745 (CAS, UC); Lakes Ridge, above Maricopa Road on Matilija-Sespe divide, Pollard 1955 (CAS, COLO, TEX); $0.25 \mathrm{mi}$. NW of Reyes Peak, 23 Apr. 1934, Sowder 393 (UC).

Thermopsis californica var. argentata differs from the more widespread, more variable variety californica in its smaller habit and closely appressed, silvery vestiture.

We are unable to distinguish between the northern and southern populations (Fig. 1). Isely (1981) applied the varietal name argentata (as part of his T. macrophylla) only to the more northern populations and included the southern populations in his T. macrophylla var. macrophylla. We agree with the assessment of Abrams (1944) that these disjunct interior populations represent a single taxon. At least we can find no characters by which to distinguish them though both are readily distinguished from varieties californica and semota by habit, vestiture, and petal shape.

1b. Thermopsis californica var. californica.

Thermopsis californica var. velutina E. Greene, Erythea 1: 81. 1893. Thermopsis velutina (E. Greene) E. Greene, Erythea 3: 19. 1895. Thermopsis gracilis var. velutina (E. Greene) Jepson, Man. Fl. Pl. Calif. 515. 1925. Thermopsis macrophylla var. velutina (E. Greene) Larisey, Ann. Missouri Bot. Gard. 27: 256. 1940. TYPE: U.S.A. California: Santa Clara Co., Mount Hamilton, Greene 1891 (lectotype, selected here, ND; isolectotype, ND).

In his protologue $\mathrm{W}$ atson did not cite specimens, but rather referred to the species as occurring in "Marin and Napa Counties, California, and probably southward." He did say that his Thermopsis californica was the same as what Torrey had referred to as "T. macrophylla" (Torrey, 1857) and T. "fabacea" (Torrey, 1859). Watson, in his protologue, indirectly suggested a lectotype with his citation of the Pacific Railroad Report in which Torrey cited a Bigelow collection from "Corte Madera," which is located in Marin County, California. We have selected the Bigelow collection from among contending lectotypes since the Torrey Herbarium collection at NY has the name Thermopsis californica Watson written on it, presumably in Watson's hand. Duplicates of the Bigelow collections were not found at GH, where Watson worked, nor were other contending lectotype collections annotated by him as belonging to Thermopsis californica.

Plants 3-8(-9) dm tall, sparsely to densely tomentose or villous; branches weakly to moderately zigzagged. Leaflets elliptic to obovate or rhombic, $3.5-7(-9) \mathrm{cm}$ long, $2-4(-4.5) \mathrm{cm}$ wide, obtuse to acute; petioles $1.5-3.5 \mathrm{~cm}$ long; stipules widely ovate to narrowly ovate, $2.5-6.5 \mathrm{~cm}$ long, $1.5-$ $5.0 \mathrm{~cm}$ wide, cuneate to amplexicaul. Racemes 


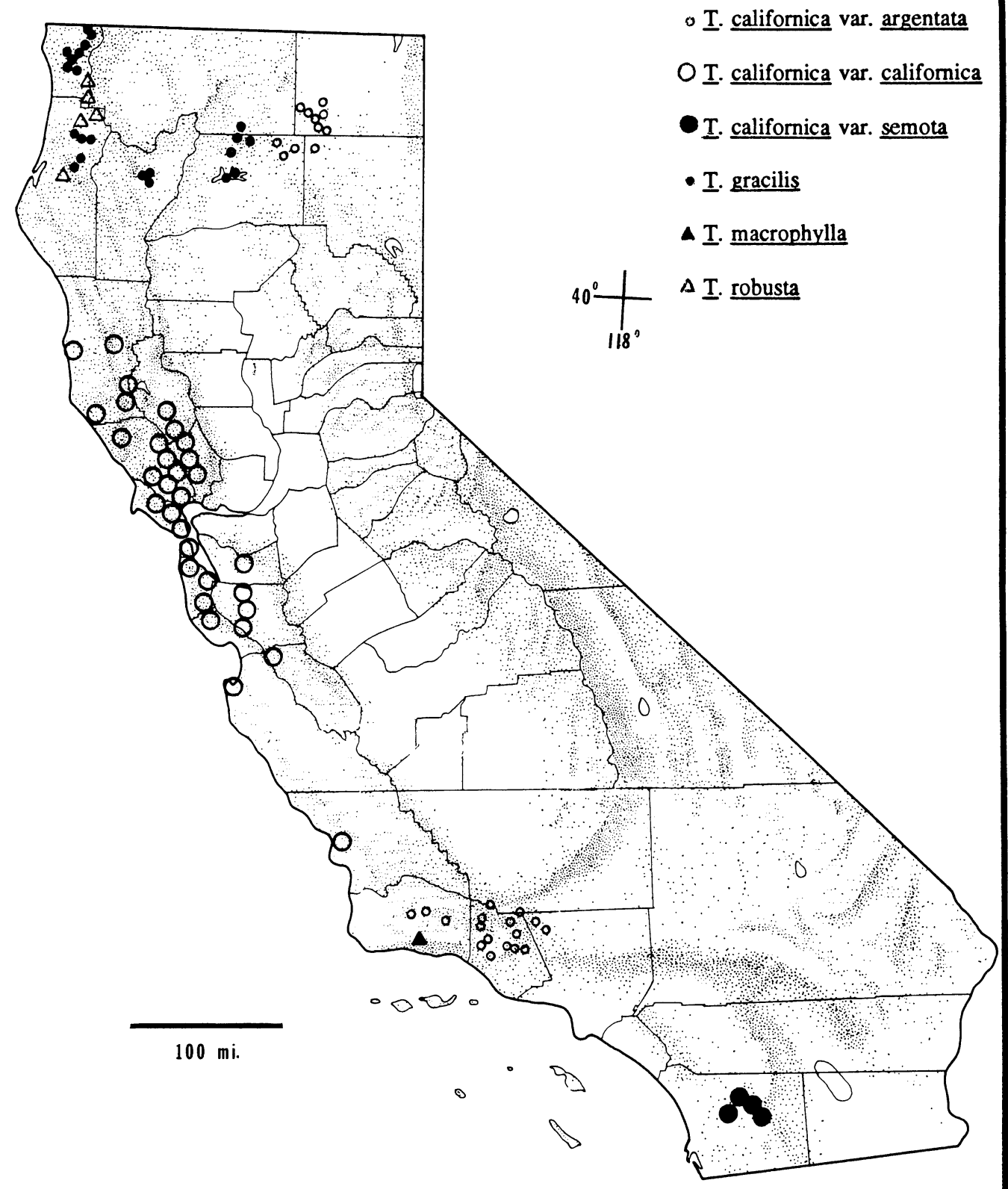

Figure 1. Distribution of Thermopsis in California: T. californica var. argentata (small open circles); T. californica var. californica (large open circles); T. californica var. semota (large closed circles); T. gracilis (small closed circles); T. macrophylla (closed triangle); T. robusta (open triangle).

10-30(-35) cm long, with 12-40 flowers; peduncles $(4-) 6-10 \mathrm{~cm}$ long; bracts widely ovate to nearly lanceolate, $6-15(-30) \mathrm{mm}$ long, $3-15(-20)$ mm wide. Calyx 5-8(-9) mm long, 6-9 mm wide at the limb, lobes $2.5-5 \mathrm{~mm}$ long; banner cleft; wing and keel petals asymmetrically oblong-elliptic; ovules $5-8$. Pods $3-5.5 \mathrm{~cm}$ long, $0.6-0.7 \mathrm{~cm}$ wide. Seeds $3-5(-10)$, oblong, $4 \mathrm{~mm}$ long, $2.8 \mathrm{~mm}$ wide. 
Distribution and ecology (Fig. 1). Coastal regions of central California from 35 to $40^{\circ} \mathrm{N}$ latitude, mostly chaparral from near sea level to about $1000 \mathrm{~m}$; flowering May-June.

Representative specimens examined. U.S.A. California: Alameda Co., hills $\mathrm{E}$ of Oakland, 1 Apr. 1929, Tebbe 62 (UC). Lake Co., $9 \mathrm{mi}$. from Lower Lake on Monticello Road, 23 May 1937, Ewan 10352 (COLO, MO, NY); flats near Morgan Valley, 25 May 1920, Jepson 9034 (JEPS). Marin Co., Sausalito to Larkspur, 27 Apr. 1918, Abrams 6882 (CAS, NY, US); San Rafael, dry hillsides, Bolander 1860-1867 (F, MO); Angel Island, San Francisco Bay, Chestnut 1888 (F, UC, US); Lagunitas, Grinnell 1918 (CAS, MO, NY, RM, UC); Tiburon, 17 Apr. 1938, Rose 38146 (GH, MO, NY, WTU, UC). Mendocino Co., 5 mi. E of Point Arena, 29 May 1939, Rose 39184 (GH, MO, NY, UC, US); Little Lake Valley $2.5 \mathrm{mi}$. SE of Willits, Wiggins \& Ferris 10183 (CAS, RM, TEX, WS, WTU). Monterey Co., hill near Monterey, 13 June 1861, Brewer 704 (UC, US). Napa Co., Knoxville, 8 May 1903, Baker 3081 (F, GH, LL, MO, NY, UC); 5 mi. S of Calistoga, 12 Apr. 1924, Heller 13837 (CAS, F, MO, NY, US). San Benito Co., Aromas, Hickman 1915 (CAS, GH, US). San Luis Obispo Co., along old road to Pozo, 17 May 1928, Eastwood 15140 (CAS, UC); San Luis Obispo, 9 May 1882, Jones 2660 (CAS, MO, NY, PH, RM, UC). San Mateo Co., Crystal Springs Lake, May 1903, Elmer 4824 (ARIZ, CAS, MO, NY, OSC, UC, US, WS); Crystal Springs Lake, 1 May 1902, Greene 685 (CAS, GH, LL, MO, NY, UC, US, WTU); Mt. Hamilton, June 1903, Elmer 5023 (ARIZ, CAS, MO, NY, UC, WS); Smith Creek, foot of Mt. Hamilton, 10 May 1907, Heller 8518 (CAS, GH, F, MO, NY, PH, UC, US, WTU); trail to Pine Ridge, $\mathrm{N}$ of Madrone Springs, 29 May 1895, Smith 4075 (GH, OSC, RM, TEX). Santa Cruz Co., Glenwood, Davis 1907 (CAS, GH, RM, UC, US); Bear Creek Road about 3 mi. E of Boulder Creek, 18 May 1946, Ferris 11130 (CAS, GH, RM, TEX, UT, WS). Sonoma Co., between Santa Rosa and Agua Caliente, 22 Apr. 1902, Heller \& Brown 5343 (CAS, COLO, GH, MO, NY, RM, US); $6.8 \mathrm{mi}$. E of Santa Rosa on road to Calistoga, 30 Apr. 1949, Wiggins 12058 (CAS, UC, WTU).

This is the more commonly encountered, more variable taxon of the Thermopsis californica complex. It is distinguished from both $T$. californica var. semota and T. californica var. argentata by its larger habit, broader stipules and bracts, and sparsely to densely tomentose vestiture.

Brewer \& Watson (1880) correctly noted that Thermopsis macrophylla is distinct from $T$. californica. Nevertheless, most workers have treated these taxa as synonymous with the earlier name, Thermopsis macrophylla. We view T. macrophylla, like Brewer \& Watson, as a localized endemic that is restricted to the Santa Ynez Mountains near Santa Barbara, California. Collections of Thermopsis californica are not sympatric and do not intergrade with T. macrophylla. Isely (1981), who treated T. californica var. californica within his concept of T. macrophylla var. macrophylla, perceived "a cline towards [T. macrophylla] var. venosa $[=T$. gracilis in the present treatment] that characteristically has spreading and (comparatively) narrow fruits." This statement was qualified by the remark that "few specimens possess mature pods." Examination of many diverse specimens from northern California shows that the geographical hiatus shown by Isely in mapping the two taxa is real, and that the few collections of his T. macrophylla var. macrophylla that he maps within the range of $T$. gracilis (of the present treatment) are mostly nonfruiting forms of $T$. gracilis that are otherwise superficially similar to $T$. macrophylla var. macrophylla (sensu Isely). We do not see any evidence of clinal intergradation between these two taxa, nor do they co-occur, as suggested in Isely's treatment.

\section{1c. Thermopsis californica var. semota} (Jepson) C. J. Chen \& B. Turner, comb. nov. Basionym: Thermopsis macrophylla Hook. \& Arn. var. semota Jepson, Fl. Calif. 2: 245. 1936. Thermopsis macrophylla Hook. \& Arn. subsp. semota (Jepson) Beauchamp, Phytologia 59: 439. 1986. TYPE: U.S.A. California: San Diego Co., Spencer Valley, vicinity of Julian, Alderson 1898 (holotype, UC).

Plants 3-5(-6) dm tall, densely silvery tomentose; branches moderately to strongly zigzagged. Leaflets elliptic to narrowly elliptic, 3-6.5(-7.5) cm long, 1.2-3.5(-3.8) $\mathrm{cm}$ wide, acute to obtuse with a short mucro; petioles $1-2 \mathrm{~cm}$ long; stipules ovate to lanceolate, $1.5-5.5 \mathrm{~cm}$ long, $0.7-2.4 \mathrm{~cm}$ wide, cuneate to cordate. Racemes $7-20(-30) \mathrm{cm}$ long, with 10-30 flowers; peduncles 2-6(-9) cm long; bracts ovate to nearly lanceolate, 6-11 mm long, 3.5-6 mm wide. Calyx 5-8(-9) $\mathrm{mm}$ long, 5-8 $\mathrm{mm}$ wide at the limb, lobes $3-5 \mathrm{~mm}$ long; banner shallowly emarginate and short mucronate; wing and keel petals asymmetrically oblong-elliptic; ovules 5-7. Pods $2-4 \mathrm{~cm}$ long, $0.6-0.7 \mathrm{~cm}$ wide. Seeds $1-2$ (fully matured not seen).

Distribution and ecology (Fig. 1). Interior portions of San Diego Co., California, grassy oak woodlands, 1000-1500 m; flowering April-June.

Representative specimens examined. U.S.A. California: San Diego Co., $1.7 \mathrm{mi}$. NW of Julian, $5 \mathrm{Apr}$ 1957, Bacigalupi et al. 5799 (JEPS, RM, WTU); near Julian, Epling 1932 (CAS, NY, POM, UC); Cuyamaca Reservoir, 5 June 1946, Fiker 3576 (RM, UC, WS) Julian, Cuyamaca Mts., 28 May 1899, Hall 1205 (CAS NY, UC); vicinity of Santa Ysabel, Henshaw 1893 (US); 
Laguna Mts., 25 June 1924, Munz 8377 (GH, NY, POM); Pine Hills, l June 1917, Spencer 504 (GH, NY, POM, UC); Ramona, head of Cedar Creek, 27 Mar. 1934, Wieslander 447 (UC).

Isely (1981) treated this taxon as a localized variety within his concept of Thermopsis macrophylla. We agree with his circumscription. Larisey (1940) inexplicably omitted the taxon from her treatment.

2. Thermopsis divaricarpa Nelson, Bot. Gaz. 25: 275. 1898. Thermopsis rhombifolia var. divaricarpa (Nelson) Isely, Brittonia 30: 470. 1978. TYPE: U.S.A. Wyoming: Albany Co., Johnson's ranch, Big Laramie River, 8 Aug. 1897, A. Nelson 3903 (lectotype, selected here, RM; isolectotypes, GH, NY [dated 7 Aug. 1897], RM).

Thermopsis pinetorum E. Greene, Pittonia 4: 138. 1900. TYPE: U.S.A. Colorado: Saguache Co., below Marshall Pass, Greene 1896 (lectotype, selected here, $\mathrm{ND}$; isolectotype, ND).

Two different collections of Thermopsis divaricarpa, E. Nelson 3424 (Pole Creek, 22 July 1897) and $A$. Nelson 3903, were designated as "type specimens" by A. Nelson, without indication of the holotype. Isely (1978) designated Nelson 3903 as the "holotype"; he should have designated this as a lectotype.

In his protologue for Thermopsis pinetorum, Greene cited collections made by himself "in fruit, below Marshall Pass," 4 Sep. 1896 and collections by C. F. Baker at Los Pinos (which is near Bayfield in La Plata Co.), 23 May 1899, in flower. The latter collections appear to belong to Thermopsis montana. The former is selected as the lectotype since mature fruits best serve to distinguish between the taxa concerned.

Plants delicate, 3-6(-9) dm tall, glabrate or puberulent; stems slender, erect, clustered, moderately branched, arising from a thick woody rootstock or rhizomes; branches ascending at $20-35^{\circ}$, moderately to strongly zigzagged. Leaflets elliptic to narrowly elliptic or rhombic, 3-7 cm long, $0.5-$ $2.5 \mathrm{~cm}$ wide, acute to obtuse, glabrate to puberulent, lateral veins $7-10$ pairs, conspicuously netveined beneath; petioles $1-2.5 \mathrm{~cm}$ long; stipules persistent, ovate to narrowly elliptic, $2-3.5(-4) \mathrm{cm}$ long, 0.7-3 cm wide, cuneate to cordate, acute. Racemes 7-15 cm long, with 5-15 flowers, usually in whorls of 2-4; peduncles $3-5 \mathrm{~cm}$ long; pedicels 5-8 mm long, glabrate to puberulent; bracts deciduous, ovate to lanceolate, $7-14 \mathrm{~mm}$ long, 3-5 $\mathrm{mm}$ wide. Flowers 2.5-2.9 cm long; calyx 8-11 $\mathrm{mm}$ long, 6-8 $\mathrm{mm}$ wide at the limb, lobes $2-5$ mm long, as long as or shorter than tube; wing and keel petals elliptic to asymmetrically oblong-elliptic; ovary appressed pubescent; ovules 10-18. Pods straight to arcuate to ca. $45^{\circ}$, divergent, 6.5-9 $\mathrm{cm}$ long, $0.6-0.8 \mathrm{~cm}$ wide, inconspicuously appressed pubescent. Seeds (6-)10-14, brown-black, elliptic with a rostrum, 4-5 mm long, $2-2.5 \mathrm{~mm}$ wide. Chromosome number, $2 n=36$.

Distribution and ecology (Fig. 2). South-central Wyoming (mainly Albany Co.) southeastward through the front range of the Rocky Mountains to northeasternmost New Mexico, mostly pine or spruce forests, usually along streams or in moist open areas, 2000-3000 m; flowering (April-)MayJune(-July).

Representative specimens examined. U.S.A. Colorado: Alamosa Co., near S entrance of Great Sand Dunes National Monument, 18 May 1969, Dennam 2950 (TENN). Boulder Co., Boulder, 21 Aug. 1884, Letterman 141 (MO, US); plains and foothills near Boulder, July 1902, Tweedy 5158 (NY, RM). Chaffee Co., Salida, 18 May 1925, Nelson 10495 (NY); Salida, 7-8 Oct. 1918, Eggleston 15019 (US). Clear Creek Co., Idaho Springs, rocky hillsides, 15 May 19l6, Clokey 2676 (RM, UC) Chicago Creek, 11 July 1942, Ehlers 8398 (COLO, TEX); Empire, 2,576 m, 15-25 July 1903, Tweedy 5652 (NY, RM). Costilla Co., mountain near La Veta Pass, 20 June 1900, Rydberg \& Vreeland 5935 (NY). Custer Co., North Creek Campground, 30 May 1954, Douglass 58 (COLO); Sangre de Cristo Creek, 2 July 1900, Rydberg \& Vreeland 5933 (NY, RM). Douglas Co., along Colorado Hwy. 67, 8.3 mi. N of junction of Colorado Hwy. 67 and County Road 126, 18 May 1987, Falb \& Miercort 113 (RM). El Paso Co., Colorado Springs, Jones 1879 (ARIZ, NY, US); near Palmer Lake, 21 June 1936, Rollins 1187 (GH, MO, ND, NY); Garden of the Gods, Schallert 1943 (F, NY, PH, WS). Fremont Co., near Hillside, 4 June 1949, Gates 22053 (TEX). Garfield Co., White River, Grizzly Creek, 26 June 1932, Ware 24 (RM); 38.8 mi. S of junction Colorado Hwy. 64 on Colorado Hwy. 139, 14 June 1971, Wofford 1-77 (TENN). Gilpin Co., near summit of Black Hawk Pass, Alston 1964 (TEX); Tolland, Overholts 1913 (MO, NY). Grand Co., Trail Ridge Road, 11.5 mi. N of Grand Lake, 21 July 1961 , Douglass 320 (TEX); Hot Sulphur Springs, 30 May 1940, Pohl 1954 (PH). Huerfano Co., 8 mi. SW of Cuchara, Bear Lake Camp, 4. Aug. 1970, Stephens \& Brooks 42675 (NY, UC); Erwind Canyon, W of Walsenburg, 14 June 1941, A. \& R. A. Nelson 4595 (RM). Jackson Co. Gould Ranger Station, 23 Sep. 1944, Ginter 891 (RM). Jefferson Co., Vernon Canyon, 20 June 1921, Bethel \& Clokey 4186 (CAS, COLO, F, MO, NY, PH, POM, RM, UC, US); near Golden, Guy Hill, 2 June 1938, Ehlers 6850 (ARIZ, GH, NCU, ND, PH); ca. $11 \mathrm{mi}$. W of Littleton, 20 May 1967, Turner 5637 (CAS, RM, TEX). Lake Co., Everett, 7 May 1919, Clokey 3588 (CAS, F, GH, MO, POM, RM, TEX, US). Larimer Co., Estes Park, May 1895, Baker 2581 (COLO, MO, NCU, WS). Las Animas Co., $11 \mathrm{mi}$. N of Stonewall, 26 May 1968, Turner 5772 (TEX). Mesa Co., 13 Aug. 1981, Siplivinsky 1961 


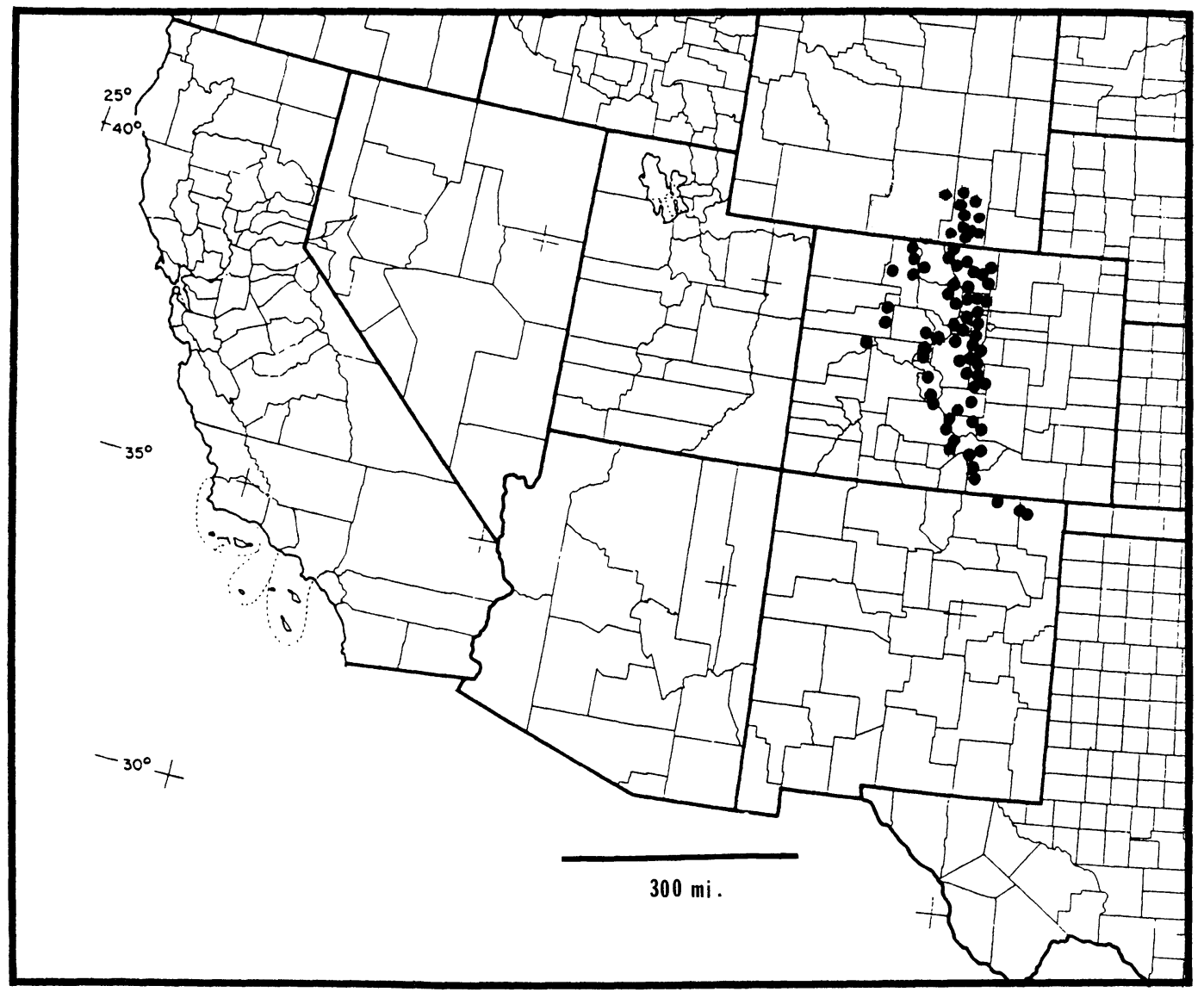

Figure 2. Distribution of Thermopsis divaricarpa.

(COLO). Park Co., Pine Junction to Wandcrest Park, 27 June 1971, Kathleen \& Shea 65 (MO); near Jefferson, Michigan Creek drainage, 16 July 1960, Walter 369 (COLO). Pueblo Co., near Beulah, 6 June 1908, Robbins 4991 (COLO); W of Pueblo, 8 May 1908, Robbins 4991 (COLO). Routt Co., Elkhead Mts., 10 July 1988, Flock 2004 (COLO, RM); Anita Peak, 3 Aug. 1903, Goodding 779 (CAS, COLO, GH, MO, NY, PH, RM, UC, US). Saguache Co., Marshall Pass, 19 July 1901, Baker 485 (F, MO, NY, RM, UC, US); 8 mi. E of Marshall Pass, 27 May 1968, Turner 5776 (TEX). Summit Co., near Breckenridge, Mackenzie 256 (MO, NY, RM, UC); near Bear River, 30 June 1926, Payson 4833 (GH). Teller Co., S side of Lower Twin Rocks Road, 10 June 1987, Barzee et al. 717 (COLO); $6 \mathrm{mi}$. NNW of Woodland Park, Devender \& Kearns 1977 (ARIZ). New Mexico: Colfax Co., Cimarron Pass, 28 May 1934, McKelvey 2405 (GH); Raton, 10 June 1887, Evans 59 (NY). Union Co., Sierra Grande, 19 June 1911, Standley 6140 (US); $7 \mathrm{mi}$. S of Des Moines, 14 May 1974, Stephens 75588 (NY). Wyoming: Albany Co., Vedauwoo Hills E of Laramie, 13 June 1940, Cain 65 (MO, TENN); Little Laramie River, 15 June 1901, Goodding 10 (CAS, F, GH, MO, NY, POM, RM, UC, US, UT); Rock River, 30 June 1914, Macbride 2403 (RM, WS); Big Laramie River, 5 July 1900, Nelson 271 (GH, NY, RM); Sand Creek, 2 June 1900, Nelson 7031 (CAS, COLO, GH, MO, NY,
POM, RM, UC, US); Mandel, 24 July 1903, Nelson 8910 (COLO, GH, MO, NY, UC); Fish Creek, 4 July 1917, Nelson 9784 (GH, MO, RM, TENN, UC); Pole Mt. region, 6 July 1943, Porter 3245 (CAS, GH, MO, NY, UC, US, WTU); Crow Creek, Laramie Hills, 11 July 1935, Rollins 977 (GH, MO, NY, WS); Laramie River near Laramie, 16 June 1935, Williams 2214 (GH, MO, UC, US); near Crow Creek, Laramie Mts., 20 June 1935, Williams 2236 (GH, MO, UC, WS). Carbon Co., McFadden, in Medicine Bow Mts., 13 June 1972, Jones 1085 (MO).

Isely (1981) treated this taxon within his broad concept of Thermopsis rhombifolia, noting that it stands morphologically and geographically somewhat between $T$. rhombifolia and T. montana, which it does. Nevertheless, we have retained $T$. divaricarpa as a distinct species.

We have found that T. rhombifolia, T. divaricarpa, and T. montana are clearly distinct throughout most of their ranges and do not appear to intergrade as do the varieties in the Thermopsis montana complex. Indeed, in Colorado where the several taxa are partially sympatric, $T$. rhombifolia 
occurs mostly at lower elevations in deeper and drier alluvial soils, T. divaricarpa at mid-elevations in mesophytic habitats, and T. montana at higher, subalpine elevations.

It is true, however, that occasional intermediates between Thermopsis divaricarpa and T. rhombifolia occur, but we view such variation as derived from relatively isolated hybridization events. Such "hybridized" populations occur in Albany County, Wyoming, and probably occasioned the description of $T$. arenosa, which appears to combine some of the features of $T$. divaricarpa in the genetic backdrop of T. rhombifolia. Likewise, in Colorado at Marshall Pass along the Saguache-Chaffee county line, T. montana and T. divaricarpa occur in close proximity and there has apparently been some gene exchange between the two. The variants from this region have the general habit of $T$. divaricarpa, but the ascending pods approach those of T. montana. The form may have precipitated the description of $T$. pinetorum. The third author visited the general area of the type locality of $T$. pinetorum in May 1968 (Turner 5776, TEX) and again in July 1991, and was impressed by the populational variation in that vicinity, especially along the eastern slopes leading to Marshall Pass. But such morphological aberrations are mere wrinkles in the broad distributional fabric of T. rhombifolia, $T$. divaricarpa, and T. montana and do not make a case for their taxonomic submergence. If it were so, then many distinct species among the closely related genus Baptisia would be merged, for occasional or even rampant hybridization is the rule when species of these taxa occur together (under disturbance). Indeed, interspecific hybridization between the closely related taxa $T$. rhombifolia, $T$. divaricarpa, and T. montana is apparently much less common than among the more distantly related (among themselves) species, Baptisia leucophaea, B. sphaerocarpa, and B. leucantha (Alston \& Turner, 1963).

It is indeed likely, however, that $T$. divaricarpa had an amphiploid origin from T. rhombifolia and T. montana. So far as is known, $T$. divaricarpa is tetraploid with $2 n=36$ and has morphological features somewhat intermediate between the diploid species T. rhombifolia and T. montana, both with $2 n=18$. Perhaps the formation of amphiploids was preceded by some gene exchange between T. rhombifolia and T. montana at the diploid level. The present ranges suggest that extensive introgression between these taxa was not likely. It should prove interesting to test these various hypotheses using molecular characters. Regardless, we believe that the taxonomic community is best served at the present time with the taxonomic treatment adopted here, this being clearly depicted to those working with living populations in the field.

Isely (1981) maps, but does not cite, at least five collections of Thermopsis divaricarpa (as $T$. montana var. divaricarpa) from western Montana, but we believe these to be misidentified elements of T. montana var. montana or T. rhombifolia. In addition, he maps at least a few collections of T. divaricarpa from northeastern $\mathrm{W}$ yoming that we believe to be misidentified elements of fairly typical T. rhombifolia.

Isely (1981) included Thermopsis pinetorum as a synonym of his $T$. rhombifolia var. montana but examination of type material, as noted above, shows that the name apparently was typified by mixed collections; the lectotype belongs to his variety divaricarpa.

Nelson, in his original description of $T$. divaricarpa, provided excellent illustrations of the fruiting branches of T. montana, T. divaricarpa, and T. rhombifolia, along with a seemingly intermediate branch between $T$. rhombifolia and $T$. divaricarpa that he named T. arenosa. Although we relegate the latter name to synonymy under "typical" T. rhombifolia, in truth, T. arenosa is probably a hybrid or introgressed individual between $T$. rhombifolia and T. divaricarpa.

3. Thermopsis fraxinifolia (Nutt. ex Torrey \& A. Gray) M. Curtis, Amer. J. Sci. 44: 81. 1843. Baptisia fraxinifolia Nutt. ex Torrey \& A. Gray, Fl. N. Amer. 1: 387. 1840. Thermopsis mollis var. fraxinifolia (Nutt. ex Torrey \& A. Gray) Isely, Brittonia 30: 469. 1978. TYPE: U.S.A. North Carolina: Burke Co., Table Mountain ("Catawba Ridge" of Nuttall; Graustein, 1967), Nuttall 1816 (holotype, $\mathrm{PH}$; possible isotypes, GH, NY).

There remains a problem with the correct author citation for Thermopsis fraxinifolia. This is summarized by Wilbur (1963) who contended that the correct citation should be $T$. fraxinifolia $\mathrm{M}$. Curtis ex A. Gray (published in 1848). Isely (1978) accepted this, but he subsequently took up the citation T. fraxinifolia Nutt. ex Torrey \& A. Gray (1840) (Isely, 1981). We believe this to be the preferred citation because Torrey \& Gray (1840) cited a Nuttall specimen and quoted a description provided by him in their discussion of $T$. fraxinifolia. Contrary to Wilbur's observation, the Nuttall name was not rejected by Torrey \& Gray. They merely noted that the species had not fallen under their observation and that it was "uncertain whether it 


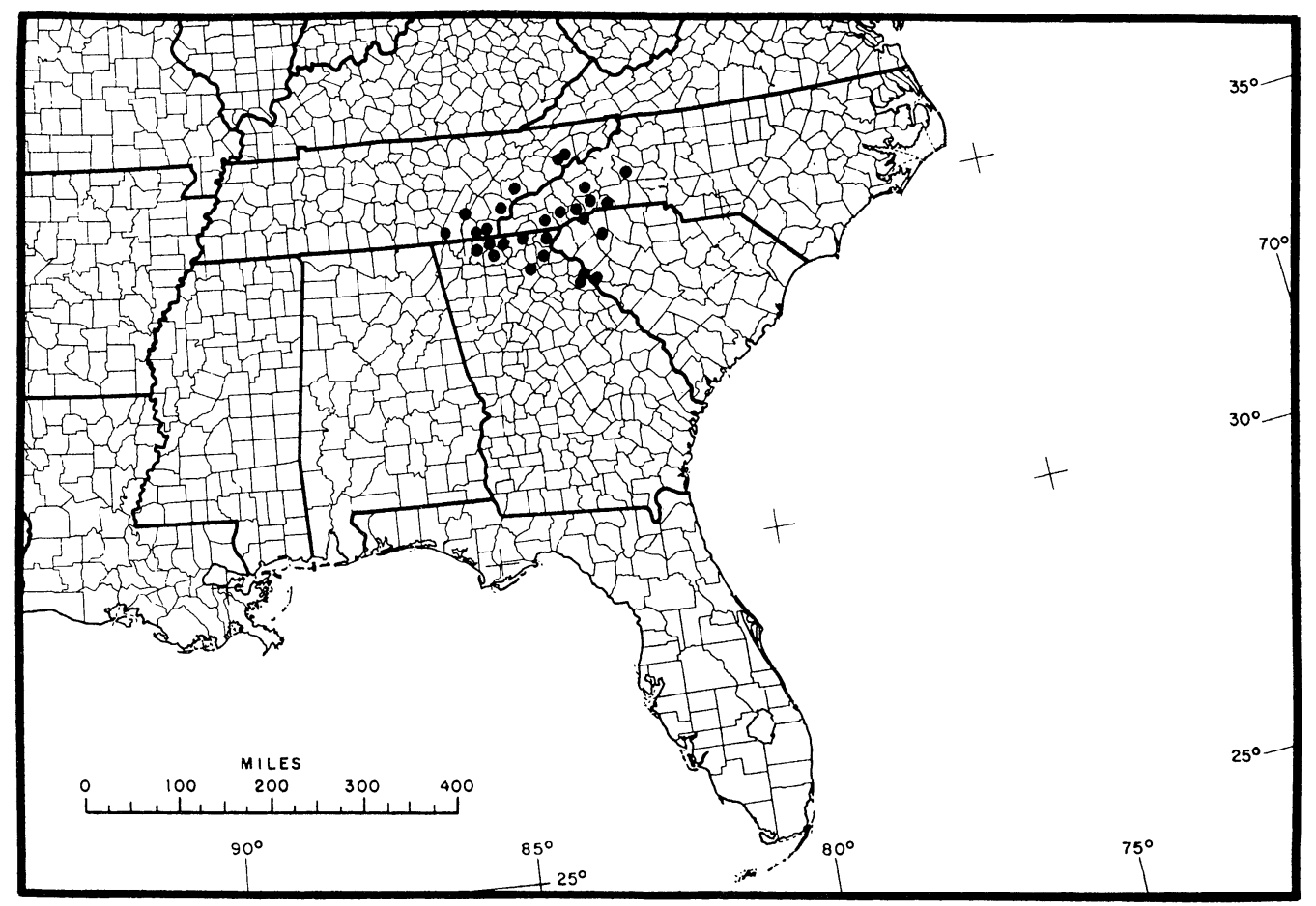

FIGURE 3. Distribution of Thermopsis fraxinifolia.

[T. fraxinifolia $]$ be distinct from some of the species described above." We do not view this as a rejection of the name, but rather a form of abeyance.

Plants delicate, 5-10 dm tall, glabrate to sparsely puberulent; stems slender, erect, clustered, wellbranched, arising from a single woody rootstock; branches spreading at $45-80^{\circ}$, strongly zigzagged. Leaflets elliptic, $4.5-8 \mathrm{~cm}$ long, $2-3.5 \mathrm{~cm}$ wide, acute to acuminate, glabrous to very sparsely puberulent, lateral veins 9-12 pairs, very conspicuously net-veined beneath; petioles $1.6-3 \mathrm{~cm}$ long; stipules sometimes persistent, lanceolate to narrowly ovate, $1-3.5 \mathrm{~cm}$ long, $0.3-0.8 \mathrm{~cm}$ wide, cuneate, acuminate. Racemes terminal or lateral, 12-25 cm long, with 7-25 flowers, scattered; peduncles 2.5-5.5 cm long; pedicels $7-17 \mathrm{~mm}$ long, glabrate; bracts persistent, lanceolate, 8-12 mm long, 1-3 mm wide. Flowers $1.6-1.9 \mathrm{~cm}$ long; calyx $7-9 \mathrm{~mm}$ long, $4-5 \mathrm{~mm}$ wide at the limb, lobes 2-3 mm long, much shorter than tube; wings elliptic to asymmetrically oblong-elliptic; keel asymmetrically oblong-elliptic; ovary appressed pubescent; ovules (6-)12-16. Pods straight, irregularly divergent, (3-)5.5-7.5 cm long, $0.3-0.5 \mathrm{~cm}$ wide, inconspicuously pubescent. Seeds (5-)1015 , brown, reniform with a very short rostrum, 4 $\mathrm{mm}$ long, $2.5 \mathrm{~mm}$ wide. Chromosome number, $2 n$ $=18$.

Distribution and ecology (Fig. 3). Southernmost Appalachian Mountains in eastern Tennessee, western North Carolina and adjacent Georgia and South Carolina, rich woods, mostly upper hillslopes along streams and at lower elevations along floodplains, (300-)700-1600 m; flowering (April-)MayJuly.

Representative specimens examined. U.S.A.Georgia: Fannin Co., NE of Cisco and NW of Blue Ridge, along Jack's Trail and Jack's River, 6 June 1983, Coile et al. 3610 (RM, TENN). Gilmer Co., near Stanley Gap, 7 June 1982, Coile et al. 2844 (POM, TEX). Habersham Co., Small 1895 (ARIZ, F, NY). Hall Co., near Gainesville, Huger 1897 (NY). Murray Co., mountain slopes between Cohutta and Fort Mountains, 27 May 1935 Duncan \& Hardin 16468 (NCU). Oglethorpe Co., ca. $0.75 \mathrm{mi}$. S of the Georgia Hwy. 368 bridge over the Savannah River, 200 m, 7 June 1979, Credle 863 (NCU); near bridge of Georgia Hwy. 72 on Savannah River, 10 June 1978, Robert \& Coile 1860 (NCU). Rabun Co., Rabun Bald, 1-4. June 1906, House 2266 (US); Tallulah Falls, Small 1893 (F, NY). Towns Co., Young Harris, 10 July 1908, Howell 390 (MO, US). North Carolina: Buncombe Co., Black Mountain, 12 Aug. 1905, Biltmore Herbarium 11214 (F, GH, MO, NY, US); Asheville, Kraus 1925 (MO, POM, UC). Burke Co., vicinity of Table Rock Mt., 2 Aug. 1890, Heller 27 (F, MO, NY, POM, UC). Henderson Co., Flat Rock, Gibbes 1854 \& 
1858 (NY). Macon Co., 1.4 mi. N of the Georgia state line on North Carolina Route 28, l June 1975, Wood $\&$ Boufford 1389 (A); $2.1 \mathrm{mi}$. N of the Georgia state line on North Carolina Route 28, l June 1975, Boufford 16075 (MO). Polk Co., Pony Mt., Townsend 1897 (US). Transylvania Co., Whitewater River, just above Upper Falls, 7 June 1951, Godfrey 51298 (MO). Yancey Co., Mt. Mitchell, Rhoades 1932 (GH, PH, RM); E of Mt. Mitchell, exactly $2.3 \mathrm{mi}$. SW of Rough Ridge Tunnel, 30 June 1970, Turner 6076 (ARIZ, CAS, F, MO, NY, TEX). South Carolina: Abbeville Co., 3 mi. SW of Calhoun Falls, near Savannah River, 13 May 1957, Radford 22768 (NCU, UC). Greenville Co., Caesars Head, Smith 1881 (F, GH, MO, NY, US). Oconee Co., Boynton 1889 (CAS). Pickens Co., 0.7 mi. off U.S. Hwy. 178 on Sassafras Mt. Road, 30 June 1970, Turner 6075 (ARIZ, CAS, COLO, F, GH, MO, NCU, NY, RM, TEX, WTU). Tennessee: Blount Co., Chilhowee Mountain, $10.98 \mathrm{~km}$ SW of Tennessee Hwy. 73 on Foothills Parkway, 650 m, 26 May 1982, Boufford \& Spongberg 22881 (A, MO, NCU, POM, TEX). Greene Co., 2.3 road mi. S of Camp Creek School, just N of Horsehitch Gap, 10 June 1980, Boom \& Smith 547 (TENN); along Kennedy Cabin loop road, 11 June 1980, Boom \& Perkins 554 (TENN); mountain slope between Camp Creek and Paint Creek on Green Mt., 30 July 1950, Shanks \& Sharp 7455 (TENN). Hamilton Co., Lookout Mt., Canby 1869 (F, GH, MO, NCU, NY, PH, US). Monroe Co., Waucheesi Mt. on FR 126-C, 12 June 1978, Whitten \& Mescall 213 (TENN). Polk Co., Peavine Road, 5.8 road mi. SW of Ocoee No. 3 Powerhouse, 23 May 1980, Boom 471 (TENN); Wolf Ridge, 25 June 1983, Z. E. \& J. B. Murrell 336 (TENN). Cultivated: Massachusetts, Botanical Garden of Cambridge, Gray s.n. (NY).

This species is partially sympatric with Thermopsis mollis, but in regions of overlap $T$. fraxinifolia usually occurs at higher elevations along the upper slopes of the mountainous ridges and hills of the Appalachians. Thermopsis fraxinifolia may also occur at lower elevations on alluvial deposits along at least some of the rivers in this region.

Thermopsis fraxinifolia can be distinguished from $T$. mollis by its more robust, more branching habit, lateral (as well as terminal) inflorescences, and longer pedicels. Furthermore, Thermopsis mollis propagates by extensive, vigorous rhizomes, which are absent in $T$. fraxinifolia. Both species were well known to Asa Gray, who personally collected $T$. fraxinifolia at its type locality and subsequently grew this at the botanical gardens at Harvard. According to Gray (1848b), T. mollis was also maintained in the Harvard Botanical Gardens at the same time. Living specimens of both were used to make the excellent illustrations of the two species that accompany his treatment of Thermopsis of the eastern United States.

As noted by Gray (1848b), Wilbur (1963), and Radford et al. (1968), Thermopsis mollis is mostly a piedmont species, distributed along the middle and western portions of North Carolina and adja- cent states, occasionally extending into the mountains, where its range abuts that of $T$. fraxinifolia. Indeed, we do not know of any specific sites where the two have been collected together, nor do we perceive a large set of intermediate plants in regions of near contact (or elsewhere) that might justify their recognition as regional variants of a single species, as treated by Isely (1981). His distribution maps of both taxa are fairly accurate, although these are difficult to evaluate since he did not cite specimens documenting the distributions shown.

Isely (1981) did map a number of specimens from easternmost Tennessee that appear to be anomalous. These are morphologically somewhere between Thermopsis mollis and T. fraxinifolia and were designated "T. mollis var.?" on Isely's map. We believe that many of these may be derivatives of hybridization between $T$. mollis and $T$. fraxinifolia. The species occur in close proximity in this region and the intermediates have the habit of T. mollis but the inflorescence pattern and general habitat preference of $T$. fraxinifolia. Both T. mollis and $T$. fraxinifolia have been collected on Lookout Mountain, Hamilton Co., Tennessee, as have several of the putative hybrid intermediates (e.g., Churchill 1911, TENN; Canby 1869, GH, MO, NCU, NY, PH, US).

More detailed field investigations may show that the hypothetical hybrids may, in fact, be part of a more widespread, highly variable taxon derived from ancestral hybridization between Thermopsis mollis and T. fraxinifolia. This is inferred from recent collections by Boufford \& Spongberg from Blount Co., Tennessee (22881, GH, MO, NCU, TEX), and by Whitten from Monroe Co., Tennessee $(213$, TENN), which seem to reveal stabilized populations of intermediate morphology in this area. Some of the characters in at least a few of these plants are unique within the American taxa of Thermopsis. For example, the Blount County specimens cited above have short, squat pods with distinct gynophores, much as occurs in some of the Asian species. On the present information, however, it is more sensible to include such plants within a variable $T$. fraxinifolia than to accord these varietal status.

4. Thermopsis gracilis Howell, Erythea 1: 109. 1893. TYPE: U.S.A. Oregon: Josephine Co., "Mountains near Waldo," 5 July 1887, T. J. Howell 669 (holotype, ORE; isotypes, CAS, $\mathrm{GH})$.

Thermopsis venosa Eastw., Bull. Torrey Bot. Club 32: 198. 1905. Thermopsis gracilis var. venosa (Eastw.) Jepson, Man. Fl. Pl. Calif. 515. 1925. Thermopsis 
montana var. venosa (Eastw.) Jepson, Fl. Calif. 2: 245. 1936. Thermopsis macrophylla var. venosa (Eastw.) Isely, Brittonia 30: 469. 1978. TYPE: U.S.A. California: Shasta (or Trinity) Co., "Lewiston Trail near the summit that divides Trinity from Shasta County, California," Eastwood 1901 (holotype, CAS). Thermopsis subglabra L. Henderson, Rhodora 32: 26. 1930. TYPE: U.S.A. Oregon: Lane Co., "Shady woods of Culp Creek, near base of Bohemia Mt. Divide, between Lane and Douglas Counties, Oregon," 1600 m, 2 May 1926, J. R. Patterson 9959 (lectotype, selected here, ORE).

In his protologue for Thermopsis gracilis, Howell did not mention a specific type but rather noted the species to occur in "Mountains of southwestern Oregon, from the sources of the Willamette, to northern California," which suggests that he knew the plant from a number of collections. Actually, there is only a single sheet at ORE that could have served as the voucher for Thermopsis gracilis. L. A. Vorobik, by annotation, selected this as the holotype. A purist might have called this a lectotype.

Plants robust, $3-8 \mathrm{dm}$ tall, glabrous to sparsely villous; stems slender, erect, single or clustered, well-branched, arising from a woody rootstock or rhizomes, branches spreading at $30-70^{\circ}$, moderately to strongly zigzagged. Leaflets elliptic to obovate or rhombic, $3-6(-8) \mathrm{cm}$ long, $2-3.2 \mathrm{~cm}$ wide, acute, obtuse, or emarginate, glabrous, lateral veins 6-9 pairs, very conspicuously net-veined beneath; petioles $2.5-4(-5) \mathrm{cm}$ long; stipules persistent, asymmetrically ovate-elliptic, $2.5-3.5 \mathrm{~cm}$ long, $1.5-3 \mathrm{~cm}$ wide, cuneate to cordate, acuminate. Racemes 12-20(-30) cm long, with 7-30 flowers, scattered; peduncles $4-9(-11) \mathrm{cm}$ long; pedicels $6-16 \mathrm{~mm}$ long, glabrous to sparsely villous; bracts semipersistent, ovate, $6-8 \mathrm{~mm}$ long, $3-5 \mathrm{~mm}$ wide. Flowers $2-2.3 \mathrm{~cm}$ long; calyx $8-$ $10 \mathrm{~mm}$ long, 7-8 $\mathrm{mm}$ wide at the limb, lobes 2$3 \mathrm{~mm}$ long, much shorter than tube; wings elliptic; keel asymmetrically oblong-elliptic; ovary sparsely villous; ovules 9-14. Pods straight, irregularly divergent, 3-6 cm long, $0.4-0.6 \mathrm{~cm}$ wide, inconspicuously pubescent. Seeds $2-8$, tan, oblong with a short rostrum, 3-4 $\mathrm{mm}$ long, $2 \mathrm{~mm}$ wide. Chromosome number, $2 n=36$.

Distribution and ecology (Figs. 1, 4). Northwestern California and adjacent Oregon, mesophytic lower montane evergreen forests, mostly 100-1200 m; flowering (April-)May-June.

Representative specimens examined. U.S.A. California: Del Norte Co., Siskiyou lowlands near Gasquet, 22 Apr. 1939, Meola 69 (OSC, UC); N side of Middle Fork of Smith River on Old Gasquet Toll Road, l June

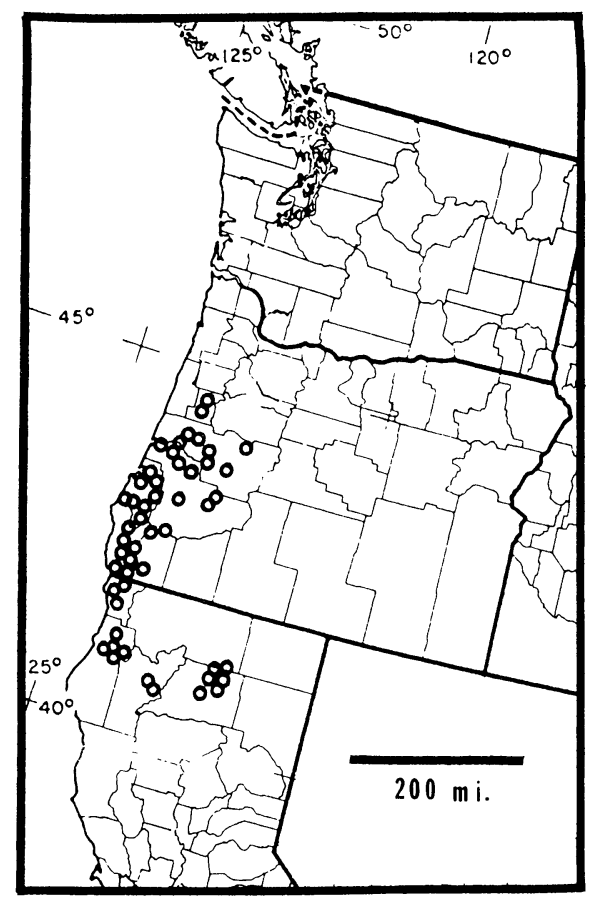

FIGURE 4. Distribution of Thermopsis gracilis.

1935, Parks \& Tracy 11227 (CAS, GH, UC, WTU); 2 mi. S of Gasquet on French Hill Road, l June 1968, Turner 5801 (CAS, GH, NY, TEX). Humboldt Co., French Camp Ridge, in chaparral, 6 Aug. 1933, Tracy 12955 (UC, WTU); Willow Creek Canyon, along Trinity Hwy., rocky point at Ruby Creek, 31 May 1937, Tracy 15326 (UC, WTU). Shasta Co., between La Moine and Williams Ranch, 19 June 1919, Heller 13250 (CAS, GH, MO, NY, PH, UC, WTU); McCloud Fork, 24 Apr. 1913, Smith 110 (GH, MO, NY). Siskiyou Co., Dunsmuir, 23 July 1912, Eastwood 1319 (CAS, GH, MO, NY, US); ca. 2 mi. S of Shasta Springs, on the old McCloud Road, 2 June 1968, Turner 5807 (TEX). Trinity Co., E of Weaver Creek, 21 May 1914, Yates 7.72 (RM, US) Oregon: Benton Co., Mary's Peak Road, ca. $10 \mathrm{mi}$. SW of Corvallis, Mills 1973 (UT); Philomath, 23 May 1925 , Stason 2399 (UC). Coos Co., $3 \mathrm{~km} \mathrm{NE}$ of Remote, 7 May 1980, Sundberg 994 (OSC). Curry Co., 2 mi. SW of turn-off from road to Agness along road to Iron Mt. 16 June 1956, Balls \& Lenz 21697 (CAS, NY, POM, RM, UC, UT, WS); Mt. Emily, lower chaparral belt, 10 Aug. 1921, Jepson \& Tracy 5909 (TEX, UC). Douglas Co., Dog Creek drainage of N. Umpqua River upstream from Steamboat River, above Limpy Rock, 19 June 1976 Chambers 4223 (CAS, NCU, POM, WTU); $10 \mathrm{mi}$. from West Fork, 27 June 1917, Peck 7255 (F, OSC). Jackson Co., Grave Creek near Winarr, 14 May 1889, Hammond 74 (MO). Josephine Co., summit of the lower Siskiyou Mts. especially N slopes, 3 July 1902, Cusick 2927 (F, GH, MO, NY, OSC, POM, UC, US, WS); Waldo, July 1894, Howell 1495 (COLO, MO, NY, ORE, OSC, PH, UC, US, WS, WTU); Onion Mt. Road, 11 May 1956 , Steward 7059 (CAS, MO, NCU, OSC, PH, POM, TENN) Sexton Mt., 9 Apr. 1934, Thompson 10209 (CAS, NY, POM, WYU). Lane Co., Spencer's Butte, 4 mi. S of 
Eugene, 5 May 1946, Baker 2791 (ARIZ, CAS, MO, NY, OSC, WTU); near Cottage Grove, Lorane Road, 17 May 1931, Henderson $13574(\mathrm{PH})$. Lincoln Co., Alsea Mts., Lammi 1939 (OSC). Polk Co., 2 mi. W of Grand Ronde, Brehm 1967 (TEX).

This species is readily distinguished from the closely allopatric Thermopsis californica and $T$. montana by its divergent pods, spreading branches, and glabrous to sparsely pubescent foliage. It is most closely related to $T$. robusta, which also has divergent pods but which differs in its very robust habit, densely pilose vestiture, and longer calyx lobes. Larisey (1940) maintained Thermopsis venosa as a variety of $T$. gracilis, but Isely (1981) treated both names as synonyms under T. macrophylla var. venosa. If Isely's treatment is accepted, the correct taxon name under the existing nomenclatural code would be Thermopsis macrophylla var. gracilis, since that combination was validated with the erection of $T$. gracilis var. veno$s a$. Regardless, we feel that $T$. gracilis is clearly distinct from T. macrophylla, as discussed in detail under the latter.

5. Thermopsis macrophylla Hook. \& Arn., Bot. Beechey Voy. 329. 1840. TYPE: U.S.A. California: Santa Barbara Co.?, spring of 1833?, probably Santa Ynez Mt., near Santa Barbara, Douglas s.n. (holotype, K; photo of holotype, POM, UC; isotype, $\mathrm{GH}$ ).

Thermopsis macrophylla var. agnina J. Howell, Leafl. W. Bot. 8: 158. 1957. TYPE: U.S.A. California: Santa Barbara Co., Camino Cielo, ca. $1 \mathrm{mi}$. W of Santa Ynez Peak. ca. 1060 m, H. M. Pollard 1955 plant B, 2 sheets (lectotype, selected here, CAS; isolectotypes, CAS [ 2 sheets plant A], US [3 sheets]).

Many workers have pondered over the type locality of Thermopsis macrophylla, equating Thermopsis macrophylla with Thermopsis californica S. Watson, but examination of type material and knowledge of the variation of Thermopsis californica throughout its range strongly suggest that Thermopsis macrophylla was originally collected in the Santa Ynez Mountains near Santa Barbara. Douglas resided for a time in Monterey, Santa Cruz County, California, from where he made several overland visits to Santa Barbara Mission. Eastwood, as noted by Howell (1957), thought she might have rediscovered the type locality of Thermopsis macrophylla in the Santa Cruz Mountains, Santa Cruz County, California, near Glenwood, but examination of this material (Davis 1907, CAS, $\mathrm{GH}, \mathrm{RM}, \mathrm{UC}, \mathrm{US}$ ) reveals these to be robust forms of otherwise typical Thermopsis californica. Howell also discussed the possible type locality of Ther- mopsis macrophylla in connection with his description of T. macrophylla var. agnina, suggesting a type locality for T. macrophylla near Aromas in San Benito County. But these, too, are merely large-leaved forms of otherwise typical Thermopsis californica. Type specimens of Thermopsis macrophylla match very closely those of $T$. macrophylla var. agnina and had Howell examined material of the Douglas collection we believe he would not have described the latter. No doubt much of the confusion regarding recognition of both Thermopsis macrophylla and T. californica is due to the fact that $T$. macrophylla is a relatively rare localized endemic. This has been confounded by the existence of Thermopsis robusta, a localized robust endemic with divergent pods, which is related to $T$. gracilis but is superficially similar to T. macrophylla in habit and vestiture. At least several workers who have recognized Thermopsis macrophylla as distinct from T. californica have treated both $T$. macrophylla and $T$. robusta as the same.

Plants robust, $12-23 \mathrm{dm}$ tall, tomentose; stems thick, erect, solitary or few, moderately branched, from a woody rootstock, branches ascending at $45^{\circ}$, moderately zigzagged. Leaflets elliptic, 4-10 $\mathrm{cm}$ long, 2-5 cm wide, villous, acute, lateral veins 6-8 pairs, not conspicuously net-veined beneath; petioles $2-5(-7) \mathrm{cm}$ long; stipules persistent, widely ovate, $3-9 \mathrm{~cm}$ long, $2-6 \mathrm{~cm}$ wide, amplexicaul to cordate, acuminate. Racemes $25-60 \mathrm{~cm}$ long, with 30-90 flowers, in whorls of 3-5; peduncles 8-15 cm long; pedicels 2.5-4 mm long, villous; bracts persistent, ovate to lanceolate, 8-10 $\mathrm{mm}$ long, 3$5 \mathrm{~mm}$ wide. Flowers $1.7-2.2 \mathrm{~cm}$ long; calyx $7-9$ $\mathrm{mm}$ long, 7-8 $\mathrm{mm}$ wide at the limb, lobes 3-4 $\mathrm{mm}$ long, as long as or shorter than tube; wings elliptic; keel obovate; ovary velutinous; ovules $7-$ 9. Pods straight, ascending, 3.5-5 cm long, 0.5$0.7 \mathrm{~cm}$ wide, villous. Seeds $5-7$, brown-black, widely elliptic with a short rostrum, 4-5 mm long, 2.5$3.0 \mathrm{~mm}$ wide. Chromosome number, $2 n=18$.

Distribution and ecology (Fig. 1). Known only from the Santa Ynez Mountains, Santa Barbara Co., California, where it is locally common on the west side of Santa Ynez Peak near the summit, in sandy granitic soils, 1000-1400 m; flowering MayJune.

Specimens examined. U.S.A. California: Los Angeles Co., Claremont, weed on the Rancho Santa Ana Botanic Garden grounds, "apparently introduced," 9 May 1991, Ross 5047 (POM). Santa Barbara Co., S slope of Santa Ynez Peak, $1130 \mathrm{~m}, 11$ May 1962, Breedlove 2695 (CAS, POM); Santa Ynez Peak, Fairfax 1977 (RM); Santa Ynez Peak, ca. 4000 ft., Pollard 1956 (CAS, 
TEX); in chaparral W of Santa Ynez Peak, 17 Oct. 1945, Smith 1620 (POM); just W of Santa Ynez Peak, 12 May 1957, Smith 5283 (POM); ca. 0.5 mi. due W of Santa Ynez Peak, 4. June 1968, Turner 5820 (GH, NY, TEX); Santa Ynez Mts., along W Camino Cielo Road, $5.5 \mathrm{mi}$. $\mathrm{E}$ of intersection with Refugio Road, $3900 \mathrm{ft}$., 26 June 1992, Junak 5022 (TEX); Santa Ynez Mts., along W Camino Cielo Road, $6.2 \mathrm{mi}$. E of intersection with Refugio Road, 4020 ft., 26 June 1992, Junak 5020 (TEX).

The relationship of this localized endemic and its longtime confusion with Thermopsis californica is discussed in the above account of its typification. The early workers, mainly S. Watson, who possessed an isotype of T. macrophylla, maintained both T. californica and T. macrophylla as conceived in the present study. Subsequent workers, mostly Californian, confounded the two taxa. The taxa were not clarified by Larisey (1940), who treated both $T$. californica and $T$. robusta as synonymous with her T. macrophylla var. macrophylla (she ignored T. macrophylla var. agnina). In this Larisey was followed by Isely (1981) who also treated all of these as synonymous with his concept of T. macrophylla var. macrophylla. To our knowledge, Douglas made only two collections of Thermopsis in California, the type of T. macrophylla and a collection of $T$. californica var. californica. Torrey \& Gray (1840) referred the latter to T. macrophylla var. $\beta$. This specimen (GH) is a fairly typical specimen of $T$. californica, presumably collected in the spring of 1833, perhaps in the vicinity of Monterey, California, to judge from its flowering state and vestiture.

6. Thermopsis mollis (Michaux) M. Curtis ex A. Gray, Mem. Amer. Acad. Arts n.s. 3: 47. 1848. Podalyria mollis Michaux, Fl. Bor.Amer. 1: 264. 1803. Baptisia mollis (Michaux) Nutt., Gen. N. Amer. Pl. 1: 281. 1818. TYPE: U.S.A. North Carolina: Mecklenburg Co., vicinity of Mecklenburg, without date, Michaux s.n. (holotype, P not seen; probable isotype, $\mathrm{PH})$.

Baptisia hugeri Small, Bull. Torrey Bot. Club 25: 139. 1898. Thermopsis hugeri (Small) Small, Fl. S.E. U.S. 596, 1331. 1903. TYPE: U.S.A. Georgia: Habersham Co., "northern slope on Mount Griffin," near Cornelia, A. M. Huger 1897 (holotype, NY; isotype, MO).

Plants delicate, 3-6 dm tall, sparsely appressed pubescent; stems slender, ascending or spreading, solitary or clustered, moderately branched, arising from extensive rhizomes; branches spreading at $45-80^{\circ}$, strongly zigzagged. Leaflets elliptic, 3.5$8 \mathrm{~cm}$ long, $1-4 \mathrm{~cm}$ wide, acute to acuminate, sparsely appressed pubescent especially on veins, sometimes glabrate above, lateral veins 7-9 pairs, very conspicuously net-veined beneath; petioles 0.7-1.7 cm long; stipules caducous, narrowly elliptic to linear, $1.5-2 \mathrm{~cm}$ long, $0.3-0.5(-0.8) \mathrm{cm}$ wide, cuneate, acuminate. Racemes terminal, $7-$ $20 \mathrm{~cm}$ long, with 5-17 flowers, scattered; peduncles 3-7 cm long; pedicels 4-6 mm long, villosulous; bracts persistent, lanceolate, 8-13 mm long, $2-4 \mathrm{~mm}$ wide. Flowers $1.6-1.9 \mathrm{~cm}$ long; calyx 7.5-8 $\mathrm{mm}$ long, 6-7 $\mathrm{mm}$ wide at the limb, lobes 2-3 mm long, shorter than tube; wings elliptic to asymmetrically oblong-elliptic; keel asymmetrically oblong-elliptic; ovary densely appressed pubescent; ovules (8-)12-16. Pods arcuate to straight, divergent, (3-)4-9 cm long, 0.4-0.6 cm wide, densely appressed pubescent. Seeds 6-12, oblong with a rostrum, $2.5-3.5 \mathrm{~mm}$ long, $1.5-2 \mathrm{~mm}$ wide. Chromosome number, $2 n=18$.

Distribution and ecology (Fig. 5). Mostly midelevations of the southern Appalachian Mountains and adjacent piedmont region of northernmost Georgia, eastern Tennessee, northwestern South Carolina, western North Carolina, and central Virginia, mostly 300-800 m; flowering (April-)MayJune.

Representative specimens examined. U.S.A. Alabama: De Kalb Co., Mentone, Loving 1899 (US). Georgia: Dade Co., $1 \mathrm{mi}$. W of Durham and NE of Cloudland Canyon, 12 May 1953, Hardin 15933 (NCU, US); Lookout Mt., 26 Apr. 1952, Harper 4204 (NY, US). Habersham Co., near Cornelia, Huger 1898 (NY). Walker Co., 22.4 mi. SE of La Fayette, 24 Apr. 1961, Turner 4691 (TEX). Whitfield Co., 4 mi. NW of Dalton, 24 Apr. 1948, Cronquist 5055 (NY); near summit of Chattoogata Mts., 19 July 1990, Harper 265 (NY, US). North Carolina: Buncombe Co., [Asheville], Biltmore, $1 \mathrm{May}-$ 10 June 1896, Biltmore 1025 (F, MO, NY, PH, RM, TENN, UC, US). Caswell Co., Milton, Fomey 1860 (PH). Catawba Co., 3 mi. SSE of Newton, 29 Apr. 1957, Bell 6822 (NC, NY); 1.25 mi. SW of Hickory on U.S. Hwy. 70, 3 May 1953, Radford \& Wood 6970 (NCU, US). Chatham Co., vicinity of Bush Creek, $3.9 \mathrm{mi}$. S of Orange Co. line on U.S. Hwy. 15 and 0.6 mi. E on paved road, 24 Apr. 1957, Ahles 23825 (GH, NCU); Edward's Mt., 3 mi. E of U.S. Hwy. 501, 6.6 mi. S of Chapel Hill, 11 Apr. 1940, Radford \& Steward 77 (NCU). Durham Co., Lynn 1933 (ND). Forsyth Co., Schallert 1940 (GH); S edge of Winston-Salem, Wherry 1928 (NY). Gaston Co., near summit of Kings Mt., 24 Apr. 1968, Leonard \& Radford 1353 (LL, NCU, OSC, TENN, TEX); Crowders Mt., 4. June 1953, Radford \& Haesloop 7089 (ARIZ, NCU). Guilford Co., Guilford College, 30 Apr. 1958, Terrell 3205 (NCU). Henderson Co., Flat Rock, Memminger 1886 (NCU). Iredell Co., $3.3 \mathrm{mi}$. W of Harmony on North Carolina Hwy. 901, 21 Apr. 1953, Daggy 2221 (NCU); Statesville, Hyams 4968 (F, MO, NY, POM). Lincoln Co., Hunter s.n. (GH, NY); near Vale, 28 Apr. 1957, Bell 6654 (NCU). Orange Co., near Hillsboro, Curtis s.n. (NY). Stokes Co., 1 mi. N of Hanging Rock, 30 Apr. 1961, Carswell 192 (NCU); above Danbury, Hunt 1936 (NCU). Surry Co., Pilot Mt., Ashe 1896 


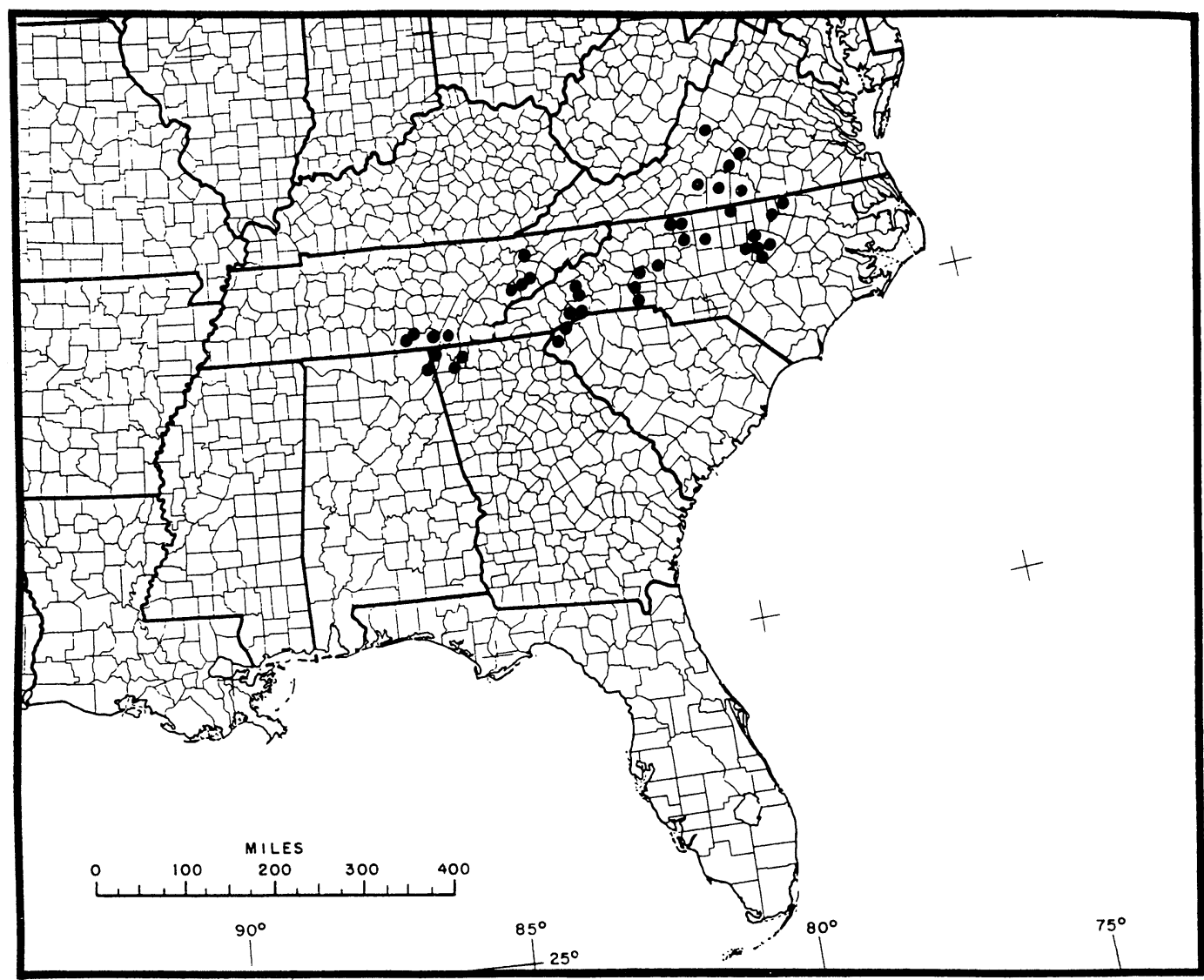

FigurE 5. Distribution of Thermopsis mollis.

(NCU); Pilot Mt., 5 May 1935, Oosting 3519 (NCU). Vance Co., Kittrell, Browne 1884 (NY); Kittrell's Springs, Faxon 1874, (GH). Wake Co., $5.5 \mathrm{mi}$. NE of Holly Springs, 28 Apr. 1954, Radford \& Beard 7984 (NCU); W of Raleigh, l mi. N of Tyson's Store, 30 Apr. 1951, Fox 4580 (MO). Warren Co., Ridgeway, 20 Apr. 1938, Godfrey 3600 (GH, NCU). South Carolina: Greenville Co., Paris Mt., Huger 1903 (NY); Paris Mt., Huger 1904 (NY). Oconee Co., Rich Mt., 5.5 mi. W of Walhalla, 16 Apr. 1967, Bozeman et al. 8862 (COLO, NCU, POM, WTU); Mountain Rest, ca. $0.5 \mathrm{mi}$. W of West Village Creek on County Route 258, 30 Apr. 1989, Hill 20511 (NY). Pickens Co., $12.5 \mathrm{mi}$. S of Rosman along U.S. Hwy. 178, l May 1941, McVaugh 5649 (GH, UC). Tennessee: Blount Co., Chilhowee Mt., 26 Apr. 1939, Jennison 299 (TENN); Chilhowee Mt., between Millstone Gap and Walland, Thomas 1965 (TENN). Franklin Co., edge of Sewanee, 3 May 1941, Sharp \& Meyer 1259 (MO, PH, TENN, UC); St. Andrews, 25 Apr. 1936, Svenson 7592 (GH, MO, PH, UC). Grainger Co., Lea Lakes, 3 May 1934, Hesler \& Sharp 566 (TENN). Hamilton Co., Lookout Mt., Churchill 1906 (GH); Lookout Mt., Churchill 1906 (GH, MO, TENN). Marion Co., W of Whitwell, 14 May 1934, Harger 7788(GH, TENN). Sevier Co., Gatlinburg entrance to Great Smoky Mountains National Park, Rogers 41851 (TENN); Chilhowee Mt., 7 May 1964, Thomas 32794 (TENN). Virginia: Bedford Co., intersection of County Route 711 and County Route 811, 11 Aug. 1985, Wright 469 (MO). Camp- bell Co., Sleepy Hollow Road, 23 May 1967, Freer 5597 (GH, NCU). Charlotte Co., 4 mi. S of Charlotte, Court House township, 16 Apr. 1967, Harvill 15436 (NCU). Halifax Co., near Halifax, Rowlett 1921 (US). Prince Edward Co., Hampden Sydney College, Blair 1981 (F, GH, MO, NY, US); Farmville, Fattig 1922 (US). Rockbridge Co., Balcony Falls, 1 May 1947, Freer $1348(\mathrm{GH})$.

The relationship of this species to Thermopsis fraxinifolia is discussed under $T$. fraxinifolia.

Fernald (1950) noted that at least one population of Thermopsis mollis from Essex Co., Massachusetts, had been introduced and naturalized in the northeastern United States, although he ignored the more widely cultivated $T$. villosa. We have examined material from Essex Co. (GH), presumably that referred to by Fernald, but it appears to be T. villosa.

7. Thermopsis montana Nutt. ex Torrey \& A. Gray, Fl. N. Amer. 1: 388. 1840. TYPE: see Thermopsis montana var. montana.

Plants delicate, $2-8(-10) \mathrm{dm}$ tall, glabrous to appressed pubescent or thinly villous; stems slender, erect, solitary or clustered, moderately or few- 
branched, arising from a woody rootstock or rhizomes; branches ascending at $20-45^{\circ}$, weakly to moderately zigzagged. Leaflets narrowly elliptic or obovate, $3.5-8 \mathrm{~cm}$ long, $0.7-3(-5) \mathrm{cm}$ wide, acute or obtuse, sometimes short mucronate or emarginate, sparsely appressed pubescent to glabrous, lateral veins 6-11 pairs, conspicuously net-veined beneath or not; petioles 1-4 cm long; stipules persistent, widely ovate or elliptic, $1.7-4.5 \mathrm{~cm}$ long, $0.7-2.5 \mathrm{~cm}$ wide, oblique to cuneate, acuminate or acute. Racemes 4-25 cm long, with 6-25 flowers, in whorls of $2-3$ or scattered; peduncles 2-8 cm long; pedicels $3.5-5 \mathrm{~mm}$ long, villosulous; bracts semipersistent, narrowly elliptic to widely ovate, 6-10 mm long, 2.5-6 mm wide. Flowers 1.6-2.2 cm long; calyx 9-1 $1 \mathrm{~mm}$ long, 5-8 $\mathrm{mm}$ wide at the limb, lobes 3-5 mm long, shorter than tube; wing and keel petals asymmetrically oblong-elliptic; ovary velutinous or densely appressed pubescent; ovules 10-16. Pods straight, erect, $4.5-6.5 \mathrm{~cm}$ long, 0.4-0.6 cm wide, villosulous or appressed pubescent. Seeds 6-16, brown-black, oblong with a rostrum, 3.5-5 $\mathrm{mm}$ long, $2.5-3 \mathrm{~mm}$ wide.

We recognize two intergrading varieties under this taxon, as follows:

\section{KeY TO VARIETIES OF THERMOPSIS MONTANA}

la. Plants less than $7 \mathrm{dm}$ tall, pubescent; stems often solitary and few-branched, often arising from rhizomes; leaflets not conspicuously netveined beneath; bracts elliptic to widely ovate 7a. Thermopsis montana var. montana

1b. Plants up to $10 \mathrm{dm}$ tall, glabrate; stems clustered and moderately branched, arising from a woody rootstock; leaflets conspicuously netveined beneath; bracts narrowly elliptic $7 \mathrm{~b}$. Thermopsis montana var. ovata

7a. Thermopsis montana var. montana. Thermopsis fabacea var. montana (Nutt. ex Torrey \& A. Gray) A. Gray, Proc. Acad. Nat. Sci. Philadelphia 1863: 60. 1864. Thermopsis rhombifolia var. montana (Nutt. ex Torrey \& A. Gray) Isely, Brittonia 30: 470. 1978. TYPE: U.S.A. Wyoming: "Rocky Mountains" [Sweetwater Co.?], Nuttall 1834 (holotype, BM not seen; photo of holotype, POM, UK; isotype, $\mathrm{PH}$; photo of isotype, POM).

Thermopsis angustata E. Greene, Pl. Baker. 3: 34. 1901. TYPE: U.S.A. Nevada: Elko Co., Star Valley, "foothills of the Ruby Mountains," E. L. Greene 1896 (holotype, ND).

Thermopsis stricta E. Greene, Pl. Baker. 3: 34. 1901. TYPE: U.S.A. Colorado: Gunnison Co., Gunnison, 24 July $1901,2330 \mathrm{~m}$, C. F. Baker 604 (lectotype, selected here, ND; isolectotypes, GH [2 sheets], NY RM [ 2 sheets], UC, US [2 sheets]).
According to the known distribution of Thermopsis montana, Nuttall would most likely have first encountered the species in Sweetwater Co., Wyoming, at about the time indicated. It is also possible that it was first collected in southeastern Idaho in early July (cf. Graustein, 1967).

Plants 2-7 dm tall, appressed pubescent to thinly villous; stems stiffly erect, solitary or clustered, few-branched, arising from a woody rootstock or rhizomes; branches moderately zigzagged. Leaflets elliptic to narrowly elliptic or obovate, $3.5-8 \mathrm{~cm}$ long, 0.7-2.5 cm wide, appressed pubescent, not conspicuously net-veined beneath; petioles $1-2.5$ cm long. Racemes 4-18 cm long; bracts elliptic to widely ovate. Flowers $1.6-2 \mathrm{~cm}$ long. Pods villosulous. Chromosome number, $2 n=18$.

Distribution and ecology (Fig. 6). Widely distributed in the intermountain region of the United States, from southwestern Montana southward to Arizona and New Mexico and northwestward to southern Idaho and adjacent $\mathrm{W}$ yoming, middle to high elevations, 2000-3200 m; flowering MayJune.

Representative specimens examined. U.S.A. Arizona: Apache Co., 1 mi. N of Alpine, 27 June 194.4, Pultz \& Phillips 1030 (ARIZ, NY, UC). Cochise Co., Barefoot Park, Blumer 1907 (ARIZ, F, GH, MO, NY, RM, US). Coconino Co., Flagstaff, 21 Apr. 1925, Nelson 10200 (GH, MO, NY, PH, POM, RM, UC, WS). Gila Co., Sierra Ancha, Aztec Peak, 1 May 1931, Harrison 7857 (ARIZ, US). Graham Co., Graham Mts., Pine Crest, 26 May 1935, Maguire 12013 (NY, WS, WTU). Greenlee Co., near Rose Peak, $43 \mathrm{mi}$. N of Clifton, 7 June 1935 , Maguire 11886 (ARIZ, GH, NY, UC). Navajo Co., head of Little Colorado, 10 July 1912, Goodding 1147 (ARIZ, NY, RM, US). Yavapai Co., S of Prescott, 2 June 1944, Clark 11770 (GH, US). Colorado: Archuleta Co., Piedra, near Piedra River, 18 June 1924, Schmoll 1122 (RM). Chaffee Co., Poncha Springs, at intersection of railroad and highway along creek bed, 27 May 1968, Turner 5777 (TEX). Clear Creek Co., Brookvale, Bear Creek, Churchill 1918 (GH, MO). Conejos Co., SW of La Jara Reservoir, 19 Aug. 1986, O'Kane \& Anderson 2618 (RM). Costilla Co., 61 mi. E of Montevista, La Veta Pass, 30 May 1934, Frederick \& Stone 608(NY). Custer Co., W of Westcliffe, trail to Lakes of the Clouds, 29 July 1950, Weber 5894 (COLO). Delta Co., Mule Park, 12 July 1962, Gierisch 2552 (RM). Dolores Co., Lone Cone, along water courses, Brewster s.n. (COLO). Eagle Co., McCoy, edge of meadow, 30 July 1898, Shear 5310 (RM). Garfield Co., Glenwood 1910 (GH). Gunnison Co., Sapinero, 19 June 1901, Baker 173 (MO, RM, ND, NY, POM, UC). La Plata Co., $10 \mathrm{mi}$. W of Durango, 20 June 1965, Strother 389 (TEX). Las Animas Co., Wilkins Creek, ca. 0.25 mi. NW of Stonewall Gap, 15 Aug. 1987, Neely 4635 (RM). Mesa Co., Uncompahgre Plateau, head of Escalante Canyon, 19 July 1982, Siplivinsky \& Beck 4251 (COLO, RM). Mineral Co., Wolf Creek Pass, U.S Hwy. 160, 3 mi. below summit on E side, 27 Aug. 1964, Turner 5099 (TEX). Montezuma Co., along Dolores Riv- 
er, Escalante Sector, Bye et al. 1978 (COLO). Montrose Co., $30 \mathrm{mi}$. SW of Montrose, 28 Aug. 1937, Rollins 1978 (CAS, GH, MO, ND, NY, RM, US). Ouray Co., Clements 1907 (NY). Rio Blanco Co., 2 mi. E of Meeker, 18 Aug. 1935, Maguire \& Piranian 12844 (MO). Park Co., Jefferson South Park, 9 Sep. 1942, Ewan 14706 (COLO). Rio Grande Co., along South Fork of Rio Grande River, 27 Aug. 1964, Turner 5095 (TEX). Saguache Co., Marshall Pass, 21 July 1960, Barrell 127-60 (US). Idaho: Bannock Co., E of Lava Hot Springs, Everson 1946 (NY). Bear Lake Co., 1.3 mi. N of St. Charles, 25 June 1967, Faircloth 4548 (NCU). Bingham Co., Ft. Hall, Everson 1942 (TEX). Caribou Co., 8 Mile Canyon, 12 mi. S of Soda Springs, 28 June 1960, Cottam et al. 16280 (UT). Cassia Co., 20 mi. S of Oakley, along Goose Creek, 2 July 1950, J. H. \& C. B. Christ 19580 (WS). Clark Co., Kaufman, near Birch Creek, 19 July 1934, Christ 5818 (NY). Elmore Co., Moore's Creek, Boise River tributary, Grandjean 155 (RM). Franklin Co., 11 mi. NE of Preston, 5 mi. up Millcreek Canyon, 14 May 1966, G. \& G. Davidse 391 (UC, US, WTU). Lemhi Co., 20 mi. E of Gilmore, along Birch Creek, 25 June 1947, Hitchcock 15766 (CAS, COLO, MO, NY, PH, POM, RM, UC, WS, WTU). Oneida Co., divide between Marsh and Malad Valleys, Coulter s.n.(PH). Owyhee Co., ca. 39 mi. S of Bruneau, 30 May 1968, Turner 5798 (NY, RM, TEX). Twin Falls Co., Twin Falls, 26 May 1912, Bennett 88 (RM). Montana: Beaverhead Co., Armstead, 20 June 1920, E. B. \& L. B. Payson 1734 (CAS, GH, MO, RM). Broadwater Co., 4 mi. SE of Townsend, 10 June 1960, Schmautz JES-345 (CAS, RM, WS). Deerlodge Co., Fishtrap, ca. 25 mi. S of Anaconda, 20 June 1944, Hitchcock \& Muhlick 9173 (CAS, GH, MO, NY, RM, UC, WS, WTU). Gallatin Co., Belgrade, low ground, 2 June 1906, Blankenship 681 (F, MO, POM, RM, UC, US). Jefferson Co., Boulder, 24 Apr. 1939, Rose 709 (RM). Madison Co., Virginia City, Swingle 1933 (RM, WTU). Powell Co., vicinity of Deer Lodge, Fitch s.n. (RM). Silver Bow Co., Lower Moose Creek, ca. 1 mi. N of Moose Creek Parking Area, 28 June 1979, Lowry 2270 (RM). Nevada: Elko Co., 3 mi. N of Ruby Valley on E side of Ruby Mts., 29 May 1968, Turner 5795 (TEX). Eureka Co., Eureka, 2 July 1904, Kennedy 838 (ARIZ, MO, RM, UC). Humboldt Co., Santa Rosa Range, NE of Winnemucca, 29 June 1967, Gentry \& Davidse 1674 (ARIZ, COLO, GH, MO, NY, OSC, POM, UC, WTU). Lander Co., Reese River Valley, U.S. Hwy. 50, along edge of Reese River, 13 June 1964, Spellenberg 370 (F, NY). Lincoln Co., Geyser Ranch, 28 May 1945, Ripley \& Barneby 6436 (NY). Nye Co., Darrough Hot Springs, Smoky Valley, 11 May 1939, Train 2743 (MO, NY, POM, TEX, UC, WTU). White Pine Co. canyon E of Mt. Grafton, 11 Aug. 1969, Holmgren \& Bethers 3861 (NY, POM, US, WTU). New Mexico: Bernalillo Co., $8.5 \mathrm{mi}$. from San Antonito, $0.7 \mathrm{mi}$. N of Capulin Spring, 21 May 1967, Turner 5649 (CAS, NY, TEX). Catron Co., Mogollon Mt., near West Fork of the Gila River, 23 Aug. 1903, Metcalfe 593 (MO, ND, NY, RM, US). Colfax Co., $1 \mathrm{mi}$. NW of Ute Gulch Camp, 17 June 1968, Hartman 1973 (RM, TEX). Grant Co., Pinos Altos, $2.6 \mathrm{mi}$. by road to Signal Peak E of New Mexico Hwy. 15, 25 May 1985, Worthington 13180 (NY, RM). Lincoln Co., Sierra Blanca, valley of Carrizo Creek, 11 June 1932, Wilkins 2402 (PH, US); McKinley Co., Long Canyon, 6 mi. S of Crownpoint, Jump 1974 (ARIZ). Mora Co., 1 mi. E of La Cueva, Stiteler 1949 (PH). Otero Co., near summit of pass between Hollywood and
Mescalero, 26 May 1934, Ferguson \& Ottley 5223 (UC). Rio Arriba Co., Ortega Mts., ca. 2 mi. W of Hopewell Lake, 17 Aug. 1984, Hill 15167 (NY). San Miguel Co., $8 \mathrm{mi}$. E of Glorietta, along the Pecos River, 9 June 1897, A. A. \& E. G. Heller 3681 (MO, NY, US). Sandoval Co., 24 mi. N of Jemez Pueblo, 6 June 1974, Atwood 6249 (NY). Santa Fe Co., near Santa Fe Recreation Area, just off New Mexico Route 475, 16 June 1964, Perdue 6047 (US). Taos Co., Penasco, Santa Barbara Canyon, 7 July 1936, Marcelline 1989 (F). Oregon: Crook Co., $5 \mathrm{mi}$. W of Prineville, 15 June 1928, Pech 15964 (OSC, PH). Grant Co., 3 mi. E of Canyon City, 5 June 1953, Cronquist 7087 (GH, NY, WS, WTU). Harney Co., 23 mi. S of Frenchglen, 16 May 1959, Cronquist 8245 (GH, NCU, NY, POM, RM, TEX, UC, WS, WTU) [approaches variety ovata]. Malheur Co., $3 \mathrm{mi}$. W of McDermitt, 25 June 1934, Peck 21734 (OSC, UC). Utah: Beaver Co., Wah Wah Mts., Birch Creek, 4 May 1937, Cottam 7109 (UT). Box Elder Co., Brigham City, 9 May 1910, Smith 2120 (GH, NY). Cache Co., 0.25 mi. E of Wellsville, 30 May 1940, Maguire 18600 (NY, WTU). Daggett Co., vicinity of Flaming Gorge, 29 May 1932, Williams 432 (GH, MO, NY, RM). Duchesne Co., 5 mi. N of Duchesne, 6 June 1979, Neese \& Welsh 7503 (NY). Garfield Co., 7 mi. SE of Boulder, Deer Creek, 4 May 1977, Foster 3661 (NY, UT). Grand Co., 2 mi. N of Warner Ranger Station, La Sal Mts., 8 July 1933, Maguire 313 (UC, WTU). Iron Co., ca. 15 mi. E of Cedar City, just W of the entrance to Dixie National Forest, 13 June 1969, Meyer 356 (UT). Millard Co., Simonsen's Ranch, along irrigation stream, 16 June 1933, Maguire \& Becraft 3932 (GH, UC). Morgan Co., flat area below dam by old gauging station, 17 May 1987, Peterson 14 (NY, UT). Piute Co., 5 mi. E of Kingston on Utah Hwy. 62, 3 May 1977, Foster 3613 (NY, RM). Rich Co., W shore of Bear Lake, 0.7 mi. E of Pickleville, 5 July 1985, Thorne 3938 (GH, MO). Salt Lake Co., vicinity of Salt Lake City, Clements 1908 (F, GH). Sevier Co., 3 mi. S of Sevier, along stream, 8 May 1937, Hitchcock 2947 (GH, RM, UC, WS, WTU). San Juan Co., ca. 80 mi. S of Moab, NW flank of Abajo Mts., 12 June 1961, Cronquist \& Holmgren 9259(GH, NY, NCU, POM, TEX, WS, WTU). Summit Co., Goodman Ranch near Bear River, 30 June 1926, E. B. \& L. B. Payson 4833 (MO, PH, POM, RM, UC, US); Uintah Co., E of Hayden, along Uintah River, 2 June 1933, Graham 8044 (F, GH, NY, US). Utah Co., near top of Price Canyon, Malburtt 1959 (UT). Wasatch Co., 6 mi. $\mathrm{N}$ of Heber City, along highway, 28 May 1968, Turner 5794A \& 5794B (TEX). Washington Co., $5 \mathrm{mi}$. SW of Enterprise at Aspen Park Spring, 10 June 1983, Atwood 9366 (NY, RM). Wayne Co., Fruita, 18 May 1956, Vickery 587 (ARIZ, GH, POM, UT, WTU). Weber Co., Huntsville, 26 May 1940, Brizzee 7794 (UT). Wyoming: Carbon Co., Baggs, 4 July 1926 , Nelson 10720 (GH, MO, RM, UC). Park Co., McCosh 1878 (NY). Sweetwater Co., Uinta Mts., Henrys Fork, river bottoms, 26 June 1902, Goodding 1192 (CAS, F, GH, MO, NY, POM, RM, UC). Uinta Co., 1 mi. S of Lonetree, 27 July 1939, Rollins \& Munoz 2903 (CAS, $\mathrm{GH}, \mathrm{US})$.

Thermopsis montana var. montana is widespread and highly variable but can usually be distinguished from variety ovata by its smaller habit, narrower leaflets and bracts, and greater tendency to spread by rhizomes. In southwestern Oregon the 


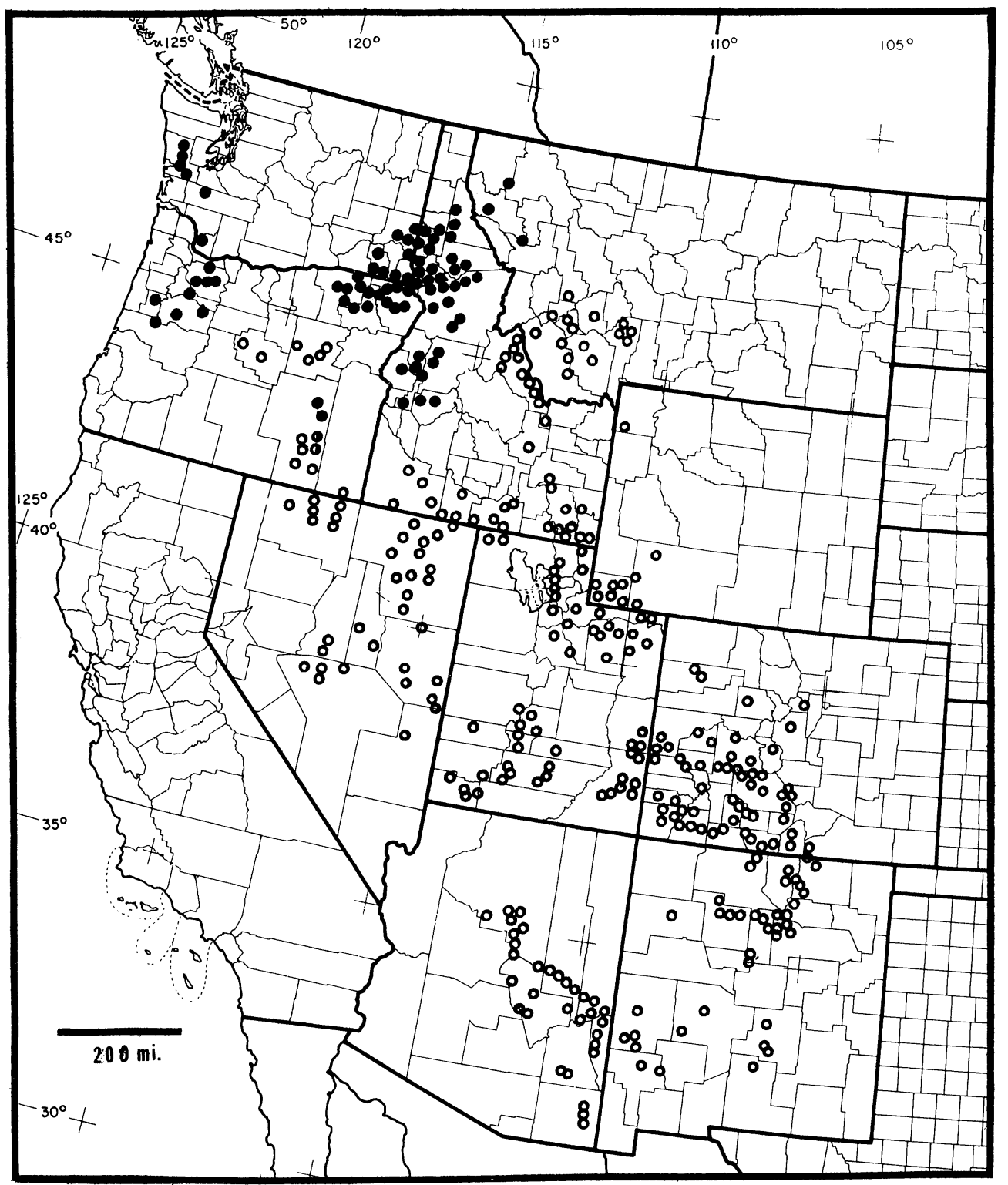

FIGURE 6. Distribution of Thermopsis montana: variety montana (open circles); variety ovata (closed circles).

taxa appear to intergrade. Isely (1981) recognized a "Lemhi race" (Lemhi County, Idaho) within the taxon we call T. montana var. montana. Though with somewhat broader leaflets, most of those specimens are fairly typical of T. montana var. montana.

In Arizona and most of New Mexico (from below San Juan and Rio Arriba counties) there also occurs a series of populations that are composed of rather broad-branching plants with leaves more or less like Thermopsis montana var. ovata. Unlike Isely (1981), we do not find such plants in Colorado.
The strictly erect pods distinguish Thermopsis montana from $T$. gracilis and from the superficially similar $T$. divaricarpa. Isely (1981) treated T. montana and T. divaricarpa as varieties of a widespread, extremely variable $T$. rhombifolia. We have found that $T$. rhombifolia, $T$. divaricarpa, and $T$. montana are clearly distinct throughout most of their ranges and do not appear to intergrade as do T. montana var. montana and T. montana var. ovata. Intermediate populations and possible hybrids are discussed under Thermopsis divaricarpa. 
7b. Thermopsis montana var. ovata (Robinson ex Piper) St. John, Torreya 41: 112. 1941. Thermopsis montana subsp. ovata Robinson ex Piper, Contr. U.S. Natl. Herb. 23: 49. 1906. Thermopsis ovata (Robinson ex Piper) Rydberg, Bull. Torrey Bot. Club 40: 43. 1913. Thermopsis rhombifolia var. ovata (Robinson ex Piper) Isely, Brittonia 30: 470. 1978. TYPE: U.S.A. Idaho: Latah Co., "Cedar Mountain," 4. July 1893, C. V. Piper 1489 (lectotype, selected here, WS; isolectotypes, GH, US, WS).

Thermopsis xylorhiza Nelson, (xylorrhiza auct.), Bot. Gaz. 52: 265. 1911. TYPE: U.S.A. Idaho: Canyon Co., Falk's Store, $667 \mathrm{~m}, 24$ May 1910, J. F. Macbride 99 (holotype, RM; isotypes, GH, MO, NY, RM, UC, WS).

Thermopsis macrophylla var. hitchcockii Isely, Brittonia 30: 469. 1978. TYPE: U.S.A. Washington: Grays Harbor Co., roadside near Humptulips, 10 July 1931 , $J$. W. Thompson 7342 (holotype, WTU; isotypes, GH, OSC, PH, POM, UC).

Piper's collection number 1489 was apparently a mixture of plants collected on 16 June 1893, 4 July 1893 (in fruit), and 21 June 1894 (in flower). We have selected the fruiting specimen as the lectotype. It is assumed that all of the collections came from the same site, although this is not certain because some of the labels (2l June 1894, NY) give the locality as "along streams in woods." The published type locality is given by Peck as "Cedar Mountain"; this locality was not on any of the labels numbered 1489 that we examined.

Plants 5-8(-10) dm tall, glabrate to sparsely appressed pubescent; stems erect, clustered, moderately branched, arising from a woody rootstock; branches weakly to moderately zigzagged. Leaflets broadly to narrowly elliptic or obovate, 4.5-6(-8) cm long, 1.5-3(-5) cm wide, sparsely appressed pubescent below, glabrous above, conspicuously net-veined beneath; petioles $3.2-4 \mathrm{~cm}$ long. Racemes 12-25 cm long; bracts narrowly elliptic. Flowers 1.9-2.2 cm long. Pods appressed pubescent.

Distribution and ecology (Fig. 6). Columbia and Snake River drainages of northern Idaho and adjacent states of Wyoming, Washington, and Oregon, with isolated populations along the Pacific coast of Washington and northwestern Oregon, $300-2000 \mathrm{~m}$ in the upper river drainages but mostly at lower elevations $(10-200 \mathrm{~m})$ about the mouth of the Columbia River and its immediate tributaries; flowering May-June.
Representative specimens examined. U.S.A. Idaho: Ada Co., 13 mi. E of Boise, Moore's Creek Canyon, 14 June 1947, J. H. \& C. B. Christ 16858 (NY). Adams Co., Davis 1939 (WS); Hornet, 13 May 1915, Mangun 139 (RM). Boise Co., 15 mi. W of Lowman, above Payette River, on road between Banks and Lowman, 31 May 1944, Hitchcock \& Muhlick 8563 (NY, WS, WTU). Butte Co., Christ 3386 (NY). Canyon Co., Falk's Store, 10 May 1911, Macbride 800 (F, GH, MO, NY, POM, RM, UC, US, WS, WTU). Clearwater Co., Clearwater Forest, Lolo Creek, 16 Oct. 1934, Christ 6322 (NY); 5 mi. W of Orofino, S side of the Clearwater River, 5 May 1951, Roeder 241 (WS). Idaho Co., $0.5 \mathrm{mi}$. from Pilot Rock, Elwood 51 (CAS, NY, POM, UC, WS, WTU); 7 mi. SE of Elk City, 14 June 1950, Jones 14 (CAS, GH, POM, WS, WTU); 2 mi. S of Grangeville, 29 May 1944, Hitchcock \& Muhlick 8455 (CAS, NY, RM, UC, WS, WTU). Latah Co., wooded hills just W of Troy, 24 May 1964, Hitchcock 23465 (CAS, NY, UC, WS, WTU). Lewis Co., Mission Creek, 30 May 1924, John et al. 6334 (UC, WS, WTU). Nez Perce Co., Aug. 1898, Brown 6 (CAS, MO, ND, NY, PH, UC, US); 3 mi. below Lowell, 30 May 1936, Constance \& Rollins 1621 (F, GH, NCU, MO, NY, RM, UC, PH, WS, WTU); near Lewiston, 7 May 1896, A. A. \& E. G. Heller 3035 (CAS, F, MO, ND, NY, PH, UC, WTU); valley of Hatwai Creek, 28 Apr. 1892, Sandberg et al. 68 (ARIZ, F, GH, MO, NY, POM, US). Shoshone Co., $8 \mathrm{mi}$. N of Calder, along St. Joe River, 19 May 1940, Christ 10969 (NY); Clearwater Camp on the Little North Fork of the Clearwater River, 4 Aug. 1941, Wilson 467 (WS). Valley Co., 5 mi. W of McCall, 24 June 1946, Hitchcock \& Muhlick 13937 (CAS, MO, NY, POM, RM, UC, WS); 9 mi. E of McCall, 11 July 1953, Holmgren \& Tillett $9542(\mathrm{GH}$, NY, OSC, UC, WTU). Washington Co., S of Council, wet meadows along highway, 11 May 1939, Cronquist 1151 (NY). Montana: Sanders Co., Dixon, 31 May 1937, Brome 28 (MO, PH, RM, WTU); 2 mi. W of Dixon, Wolf Point, 13 May 1936, Hitchcock 2877 (MO, ND, OSC, RM, WS, WTU). Oregon: Clackamas Co., Eagle Creek, high hills, 24 May 1884, Henderson 179 (OSC, PH, WS); near base of Table Rock, Leach 1927 (WTU). Linn Co., Monument Peak, Gilkey 1947 (OSC, POM). Marion Co., Silverton, Spring 1871, Hall 83 (F, POM); 6 mi. E of Brownsville, Cascade Mts., 18 June 1918, Lawrence 1751 (OSC, US); Silver Creek Falls, 19 June 1918, Nelson 2257 (GH). Polk Co., 2 mi. W of Grand Ronde, Brehm 1967 (TEX). Umatilla Co., 1 mi. SE of Meacham, 23 June 1946, Hitchcock \& Muhlick 13841 (CAS, GH, MO, NY, OSC, UC, WS, WTU); between Pendleton and LaGrande, near summit of Blue Mts., 14 June 1928, Thompson 4723 (CAS, GH, MO, US, WTU). Union Co., Kamela, 1 June 1910, Heller 10145 (CAS, GH, PH, UC); 2 mi. S of Elgin, 20 May 1975, Watkins \& Dunn 95 (MO, NY). Wallowa Co., along summit of road between Elgin and Langdon Lake, 28 July 1950, Kruckeberg 2487 (CAS, COLO, GH, NY, RM, UC); Walupi Canyon, 18 Aug. 1897, Sheldon 8724 (NY, US). Washington: Asotin Co., Snake River, just below the mouth of the Grande Ronde, 17 Apr. 1949 , Cronquist 5701 (GH, NY, POM, UC, US, WS, WTU); SW of Anatone, along Grande Ronde River, just above Rattlesnake Creek, 22 Apr. 1949, Cronquist 5709 (GH, NY, POM, UC, US, WTU). Columbia Co., Dayton, between hospital and Touchet River, 3 May 1983, Baird 51 (NY); Blue Mts., 4 mi. N of Table Rock, 20 July 1935, Constance et al. 1278 (MO, WS). Grays Harbor 
Co., $\mathrm{N}$ of Aberdeen and Hoquiam along U.S. Hwy. 101, 31 May 1987, Boufford \& E. W. Wood 23757 (A, CAS, MO, NCU, NY); ca. $20 \mathrm{mi}$. N of Hoquiam, 24 June, Hitchcock 19872 (COLO, OSC, POM, UC, WTU); between New London and Humptulips, 28 June 1933, Jones 3937 (CAS, POM, RM, UC, WTU); open burns near Humptulips, 30 May 1940, Thompson 14606 (CAS, GH, MO, NY, PH, POM, RM, UC, US). Lewis Co., Chenalis, Oxford Prairie, 12 June 1897, Lamb 1197 (CAS, F, MO, NY, PH, UC, WS). Walla Walla Co., 2 mi. S of Walla Walla, 24. May 1944, Hitchcock \& Muhlick 8274 (CAS, NY, RM, UC, WS, WTU); l mi. NE of Walla Walla, flats near Mill Creek, 2 May 1936, Moore 23 (UC, WS). Whitman Co., 1 mi. N of Colfax, 18 May 1935, Hitchcock \& Samuel 2594 (OSC, RM); Kamiack, 15 June 1893, Moore 1489 (US, WTU); Dusty, $3 \mathrm{mi}$. W of Colfax, 14 May 1922, Parker 355 (NY, OSC, POM, WS).

This variety differs from Thermopsis montana var. montana in its relatively robust habit, moderately branched stems, and broader leaflets and bracts.

Plants similar to Thermopsis montana var. ovata also occur as populational variants in Arizona, most of New Mexico, parts of southern Utah, and occasionally in Colorado, as discussed under $T$. montana var. montana. Our treatment is like that of Isely (1981), who positioned variety ovata within his broad T. rhombifolia, except that we would include his T. macrophylla var. hitchcockii within T. montana var. ovata. We do not believe that the Pacific coast plants (=T. macrophylla var. hitchcockii, sensu Isely) differ appreciably from plants of the interior montane regions that Isely places within $T$. rhombifolia. The disjunct distribution of the Pacific coastal populations is thought to represent founder populations, perhaps dispersed by periodic flooding events and subsequent establishment of propagules from populations along the upper Columbia and Snake River drainages. One may assume that these northern Pacific coast populations are more closely related to the southern populations of $T$. californica, as suggested by Isely's treatment. Although both taxa have upright pods, the distribution of $T$. californica is interrupted in Oregon by the quite distinctive $T$. gracilis, which has divergent pods. All of the specimens of T. montana var. ovata that we have examined (including the Pacific coastal populations) have strictly erect pods, yet have other characters of the Rocky Mountain species, namely $T$. montana var. montana. If one accepts the taxonomic concepts espoused by Isely (1981) in which $T$. divaricarpa and T. montana are reduced to varietal entities of a widespread, highly variable $T$. rhombifolia, one is compelled by morphological considerations to include both $T$. gracilis and $T$. cali- fornica also as part of the T. rhombifolia complex, the morphological boundaries between T. montana var. ovata and $T$. californica being at least as weak as those between $T$. rhombifolia and $T$. $d i$ varicarpa or T. montana.

8. Thermopsis rhombifolia (Nutt. ex Pursh) Richardson, Bot. App. 737. 1823. Thermia rhombifolia (Pursh) Nutt., Gen. N. Amer. Pl. 1: 282. 1818. Scolobus rhombifolius (Nutt. ex Pursh) Raf., Amer. Monthly Mag. Crit. Rev. 4: 193. 1819. Drepilia rhombifolia (Nutt. ex Pursh) Raf., N. Fl. 2: 53. 1837. TYPE: U.S.A. North Dakota: Mercer Co., near Fort Mandon, Bradbury 1810 (lectotype, selected here, PH, A. B. Lambert herbarium).

Thermopsis arenosa Nelson, Bot. Gaz. 25: 276. 1898. Thermopsis rhombifolia var. arenosa (Nelson) Larisey, Ann. Missouri Bot. Gard. 27: 251. 1940. TYPE: U.S.A. Wyoming: Albany Co., Laramie Hills, 16 June 1897, A. Nelson 3182 (holotype, RM; isotypes, ND, RM, [2 sheets] UC, US).

Thermopsis annulocarpa Nelson, Bull. Torrey Bot. Club 26: 239. 1899. Thermopsis rhombifolia var. annulocarpa (Nelson) L. Williams, Ann. Missouri Bot. Gard. 23: 450. 1936. TYPE: U.S.A. Wyoming: Carbon Co., Ferris Mountains, vicinity of Fort Steele, "among the rocks on the naked slopes near their summits," 25 July 1898, Elias Nelson 4971 (holotype, RM; isotype, NY).

Larisey (1940) designated a Nuttall collection (PH) as the type of Thermopsis rhombifolia; however, Pursh cited only a Bradbury collection, listing Cytisus rhombifolius Nutt. as a nomen nudum from Fraser's Catalogue without citing a Nuttall collection.

Plants dwarf but robust, $1.2-3 \mathrm{dm}$ tall, glabrate to appressed pubescent; stems slender, erect, or ascending, solitary or clustered, few-branched, arising from a woody rootstock or rhizomes; branches ascending at $25-50^{\circ}$, weakly zigzagged. Leaflets elliptic to obovate or narrowly elliptic, 1.7 $3.3 \mathrm{~cm}$ long, $0.6-2 \mathrm{~cm}$ wide, acute to obtuse, sometimes short mucronate, appressed pubescent to sparsely tomentose or glabrate below, glabrous above, lateral veins 5-7 pairs, conspicuously netveined beneath; petioles $0.8-2.2 \mathrm{~cm}$ long; stipules persistent, ovate to very widely ovate or elliptic to widely elliptic, $1-2.6 \mathrm{~cm}$ long, $0.5-1.5(-2.2) \mathrm{cm}$ wide, cuneate to oblique, acute to obtuse and short mucronate. Racemes 4-12 cm long, with 5-15 flowers, in whorls of 2-3 or scattered; peduncles 1-4 cm long; pedicels 3-7 mm long, glabrate to densely appressed pubescent; bracts deciduous, el- 


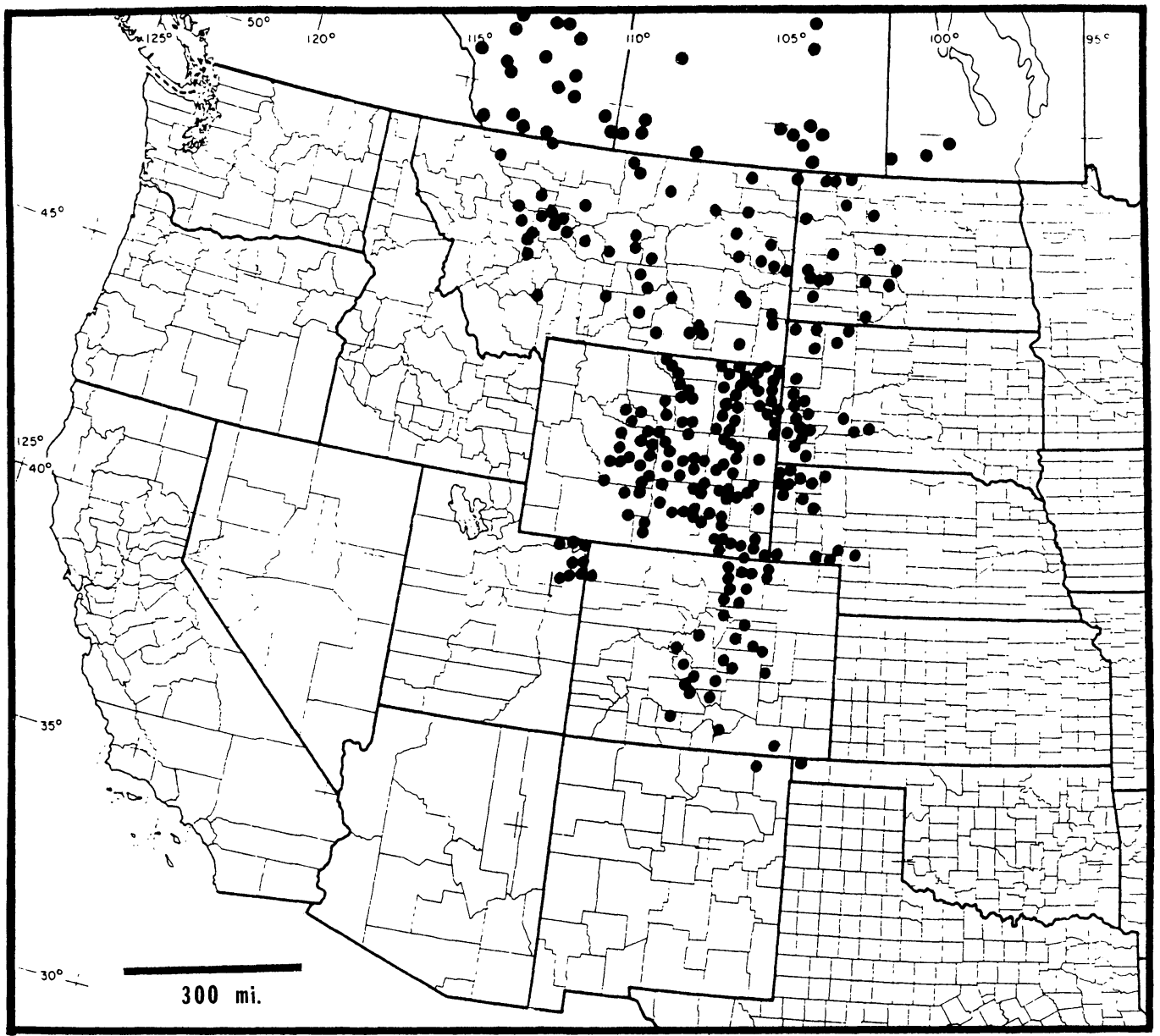

FigurE 7. Distribution of Thermopsis rhombifolia.

liptic to obovate, 5-9 $\mathrm{mm}$ long, 3-5 $\mathrm{mm}$ wide. Flowers 1.9-2.1 cm long; calyx (6-)8-10(-12) $\mathrm{mm}$ long, 4.5-6 $\mathrm{mm}$ wide at the limb, lobes (3-)4$5 \mathrm{~mm}$ long, as long as or shorter than tube; wings asymmetrically oblong-very widely ovate; keel asymmetrically oblong-widely elliptic; ovary glabrate to appressed puberulent; ovules 12-14. Pods arcuate to annular, divergent, $3-7 \mathrm{~cm}$ long, $0.4-0.7 \mathrm{~cm}$ wide, glabrate to sparsely tomentose. Seeds 2-10, brown, elliptic with a rostrum, 3.5-4 $\mathrm{mm}$ long, 2.5 mm wide. Chromosome numbers $2 n=18$.

Distribution and ecology (Fig. 7). Central Great Plains of Canada and the United States from central Alberta and Saskatchewan to northeasternmost New Mexico, largely confined to relatively xeric grasslands in deep alluvial soils but extending into the lower canyons of the front range of the Rocky Mountains, 1000-2000 m, to $3000 \mathrm{~m}$ along roadsides; flowering May-June.
Representative specimens examined. CANADA. Alberta: ca. $26 \mathrm{~km} \mathrm{NE}$ of Edmonton, $1 \mathrm{~km} \mathrm{SW}$ of Fort Saskatchewan, 20 June 1959, Shetler \& Stone 3034 (US); $20 \mathrm{~km} \mathrm{~W}$ of Cochrane, l July 1979, Watton 24 (COLO, MO, NY, OSC, PH). Manitoba: on side of Manitoba Hwy. 1 in the sand hills, 9 June 1950, Dore 10658 (GH, NY). Saskatchewan: Cypress Hills Provencial Park, 1 July 1947, Breitung 4200 (MO, RM). U.S.A. Colorado: Arapahoe Co., near Denver, 13 May 1917, Clokey 2793 (ARIZ, F, GH, RM, TEX, UC, US). Boulder Co., $10 \mathrm{mi}$. NE of Boulder, White Rocks, on Gunbarrel Hill, 18 May 1967, Turner 5634 (RM, TEX). Chaffee Co., 5 mi. SW of Buena Vista, 13 June 1967, Johnson 80 (MONTU, NCU, TEX). Douglas Co., 2 mi. W of Franktown, 27 June 1937, Beetle 1477 (CAS, NY, WTU). Elbert Co., 2 mi. N of Simla, 23 June 1937, Ownbey 1296 (COLO, GH, MO, MONTU, NY, RM, UC, WS). El Paso Co., near Ramah, 25 May 1947, Moldenke 19401 (PH, RM). Jefferson Co., E of Golden, 8 May 1941, Ehlers 8064 (COLO, TEX). Lake Co., Tennessee Fork, 16 June 1933, Applegate 8524 (F). Larimer Co., $7 \mathrm{mi}$. S of Fort Collins, 3 May 1965, Irving 6511 (TEX). Las Animas Co., $\mathrm{N}$ of Mesa de Maya, 28 Apr. 1948, Rogers 5664 (COLO, TEX). Lincoln Co., $2.5 \mathrm{mi}$. E of 
Lincoln, 7 May 1987, Falb \& Miercort $23 A(\mathrm{RM})$. Moffat Co., Blue Mountain, $8.2 \mathrm{mi}$. N of U.S. Hwy. 40, 6.5 airline mi. NNE of Dinosaur, 11 June 1971, Holmgren et al. 5162 (CAS, NY, US, WTU). Park Co., Como, 15 June 1892, Hughes 42 (GH). Saguache Co., 2 mi. S of Villa Grove on U.S. Hwy. 285, 27 May 1968, Turner 5774 (TEX). Weld Co., Pawnee Buttes, l July 1906, Dodds 2111 (COLO). Montana: Big Horn Co., road to visitor center at Yellowtail Dam, 16 May 1983, Lichvar 5666 (RM). Blaine Co., Chinook, 26 May 1937, Wellington 1049 (MONTU). Carter Co., Medicine Rocks State Park, 28 Apr. 1986, Mooers et al. 1085 (MONTU). Cascade Co., ca. 14 mi. W of Great Falls, 11 May 1956, Booth 56224 (GH, MONTU). Chouteau Co., Fort Benton, June 1883, Anderson 547 (US). Custer Co., 5 Woolfolk 1936 (GH, PH, POM, RM). Daniels Co., Von Kuster 12 (RM). Dawson Co., 5 mi. SW of Glendive, 20 May 1965, McMullin 308 (UC). Fergus Co., 3 mi. up Fords Creek turn off, 19 May 1988, Lipscomb 1 (MONTU). Gallatin Co., bench gravel, 6 July 1910, Spragg 245 (MONTU). Garfield Co., 15 mi. N of Jordan, 13 May 1968, Woodland 1632 (CAS). Glacier Co., S of Hudson Bay Divide, 31 May 1958, Harvey 66750 (MONTU). Judith Basin Co., Long's Ranch, 8 June 1900, Wilcox 388 (US). Lewis and Clark Co., ca. 4 mi. W of Wolf Creek, 2 July 1948, Hitchcock 17984 (CAS, COLO, GH, MONTU, NY, POM, UC, WS). McCone Co., Wolf Point, 19 May 1937, Buckof 546 (MONTU, WTU). Musselshell Co., Roundup, 11 May 1937, Syblon 522 (CAS, RM, UC, WTU). Petroleum Co., Flatwillow, 28 May 1936, Wickland 18(MONTU). Powder River Co., 18 May 1975, Lackschewitz 5937 (MONTU). Prairie Co., $10 \mathrm{mi}$. S of Brockway, 5 May 1941, Koch 4 (MONTU). Rosebud Co., along U.S. Hwy. 212, ca. 10-15 mi. W of Ashland, 18 July 1967, Hess 762 (MO). Sheridan Co., Westby, 17 July 1927, Larsen 20 (GH, MO, PH, RM). Sweet Grass Co., Big Coulee Creek, Blankinship 1902 (MONTU, WS, WTU). Teton Co., 22 mi. SW of Chouteau, Finley 1963 (MONTU); Collins, Jones 1904 (UC). Toole Co., Sweetgrass, Recup 1918 (NY). Valley Co., Fork Peck, 26 May 1919, Ramsden \& Lackschewitz 345 (MONTU). Wibaux Co., Hodges, Griffins 1936 (MONTU, RM, TEX, WTU). Yellowstone Co., $10 \mathrm{mi}$. NW of Billings on Lavina Road, 3 June 1973, Doles 563 (UT). Nebraska: Box Butte Co., Hemingford, 1 June 1950, Kiener 24623 (US). Cheyenne Co., 2 mi. W of Sunol, 18 May 1970, Stephens 38111 (NCU). Deuel Co., Rush Creek, Rydberg 1891 (GH, US). Keith Co., E of Cedar Point Biological Station, 7 June 1983, Sutherland 5598 (NY). Kimball Co., 8 mi. SW and $1.5 \mathrm{mi}$. S of Bushnell, 18 May 1970, Stephens 38143 (GH, NY). Garden Co., Ash Hollow State Park, W of Lewellen on U.S. Hwy. 26, 19 May 1976, Churchill 7323 (MO, NY). Sheridan Co., 13 mi. N of Hay Springs, 5 May 1964, Nixon 6 (RM). Sioux Co., 7.5 mi. S of the junction of Nebraska Hwys. $2 \& 71$ on Hwy. 71, 27 May 1972, Churchill 77 (MO, NY). New Mexico: Union Co., Capulin Mountain National Monument, 17 July 1941, A. \& R. A. Nelson 4650 (MONTU). North Dakota: Billings Co., Cedar Canyon, 9 June 1952, Clausen 8194 (GH). Burleigh Co., Bismarck, Lanterman 1891 (MO, NY, WTU). Burke Co., Portal, 18 June 1903, Barber 360 (GH). Divide Co., 25 May 1961, Stevens 2377 (UC, US). Dunn Co., Killdeer Historical Site, Stevens 1951 (US). Grant Co., Pretty Rock National Wildlife Refuge, 23 Aug. 1907, Bell 1197 (UC). Mercer Co., Missouri River Valley, $8 \mathrm{mi}$. N of Knife River, 29 June 1941, Stevens 905 (NCU, UC, US). Morton Co., Glen
Ullin, May 1891, Holzinger 5 (GH). Mountrail Co., 12 July 1960, Stevens \& Moir 2289 (NCU, UC). Slope Co., Atkinson 1935 (F, NCU, RM, UC). Stark Co., Dickinson, Whitman 1949 (US). Ward Co., Haigh 1900 (NY) Williams Co., Williston, Stevens 1918 (F). Oklahoma: Cimarron Co., N of Mesa, 28 Apr. 1948, Rogers 5664 (US). South Dakota: Butte Co., 5 mi. N of Belle Fourche, 23 May 1970, Stephens 38357 (NY). Custer Co., head of Blocktail Gulch, 12 Apr. 1910, Murdoch 4020 (F, NY). Fall River Co., Ochich, 8 Apr. 1911, Nelson 2724 (F, RM). Jackson Co., Cedar Pass, 17 July 1913, Over 6113 (COLO). Harding Co., 4 Aug. 1927, Over 17438 (US); Rabbit Butte, l May 1912, Vesher 553 (F). Law. rence Co., near Lead, 17 June 1929, Palmer 37352 (GH, MO, NY, US). Meade Co., $40 \mathrm{mi}$. NW of Rapid City, 9 July 1947, Crider \& Atkins 44 (RM). Pennington Co., Black Hills, Harney Peak, 8 July 1927, Hayward 1961 (F, RM). Perkins Co., Lemmon, Halse 1969 (OSC). Utah: Daggett Co., 6 air mi. N of Dutch John, 7 June 1979, Atwood 7284 (NCU). Uintah Co., ca. 14 air mi. NW of Vernal along Tridell-Dry Fork Road, 31 June 1983, Neese 14116 (MONTU, NY). Wyoming: Albany Co., Laramie Mts., Telephone Canyon, 30 May 1936, Ownbey 1027 (COLO, MO, MONTU, RM, WS, WTU). Campbell Co., ca. 8 air mi. SE of Reno Junction at Little Thunder Creek, 3 June 1978, Hartman \& Dueholm 5896 (NY, RM). Carbon Co., Como Bluff, 25 May 1947, Porter 4162 (CAS, MO, NY, PH, RM, TEX, UC, WTU). Converse Co., near the head of La Prele Creek, 27 June 1950, Porter 5374 (CAS, COLO, GH, MO, NY, RM, TEX, WTU). Crook Co., $8 \mathrm{mi}$. NW of Hulett, 6 June 1935, Ownbey 646 (COLO, MO, MONTU, NY, RM, UC, WS, WTU). Fremont Co., ca. 20 mi. SW of Lander along Wyoming Hwy. 28, 2 July 1983, Evert 5282 (NY, RM). Goshen Co., sandy hills between Wheatland and Veteran, 19 June 1953, Porter 6235 (RM, WTU). Hot Springs Co., $20 \mathrm{mi}$. NW of Thermopolis along Wyoming Hwy. 120, 3 July 1983, Evert 5312 (NY, RM). Johnson Co., Bighorn Mts. W of Buffalo, Circle Park, 23 July 1958, C. L. \& M. W. Porter 7562 (CAS, RM, UC, WTU). Laramie Co., Pine Bluffs, 2.5 mi. S of U.S. Hwy. 30 and Interstate Hwy. 80, 6 June 1969 Cox \& Dunn 1091 (MO). Natrona Co., 5 mi. W of Powder River, 5 July 1979, Dueholm 7760 (NY, RM). Niobrara Co., 22.5 air mi. NW of Lusk and 14.5 air mi. SW of Lance Creek, 2 June 1978, Nelson 1591 (RM). Platte Co., 21.5 air mi. N of Guernsey, 31 May 1978, Nelson 1540 (NY, RM, UC). Sheridan Co., 9 mi. S of Sheridan, 30 June 1979, Dueholm 7542 (NY, RM). Sweetwater Co., 16 mi. W of Wyoming Hwy. Rt. 789, 15 July 1973, Hill 985 (RM). Washakie Co., S of Ten Sleep, 25 July 1901, Goodding 353 (F, GH, MO, NY, RM, US). Weston Co., 3.5 air mi. NW of Osage, 22 May 1984, Marriott 6214 (NY, RM).

Larisey (1940) accepted three varieties under this species, but all of them were reduced to Thermopsis rhombifolia var. rhombifolia by Isely (1981). Although Isely's treatment extended the parameters of Thermopsis rhombifolia to include the long-recognized species $T$. montana and $T$. divaricarpa, which we do not accept, we agree that recognition of varieties within our narrower concept of $T$. rhombifolia is not justified. Thermopsis rhombifolia does not appear to intergrade with 
either T. divaricarpa or T. montana, but the occasional hybrid or hybrid swarm is believed to occur between at least $T$. rhombifolia and $T$. divaricar$p a$, especially in Albany County, Wyoming. The name T. arenosa is probably based on such hybrid variants (see discussion under T. divaricarpa).

9. Thermopsis robusta Howell, Erythea 1: 109. 1893. TYPE: U.S.A. California: "California Coast Range, near the Oregon boundary," $T$. Howell 1884 (holotype, ORE; isotypes, F, GH, NY [2 sheets], US, WS, WTU).

Some of the apparent isotypes are labeled "Coast Mts., Curry Co., Oregon" (GH) and "Oregon, Coast Mountains, fortieth parallel" (F, NY, US, WTU), while another is labeled "Oregon, Coast Mountains, forty-second parallel" (WS). We have accepted the location as given in the protologue (above), which would place the actual type locality in California, probably Humboldt or Siskiyou County to judge from the specimens we have examined.

Plants robust, 8-18 dm tall, densely tomentose; stems thick, erect, clustered, well-branched, arising from a woody rootstock; branches ascending at $30-50^{\circ}$, strongly zigzagged. Leaflets elliptic to widely elliptic or ovate, $6.5-11 \mathrm{~cm}$ long, 2.5-6.5 $\mathrm{cm}$ wide, acute to acuminate, short mucronate, tomentose, lateral veins 9-12 pairs, not conspicuously net-veined beneath; petioles $2.2-3.5 \mathrm{~cm}$ long; stipules persistent, widely ovate to nearly lanceolate, $1.5-5.5 \mathrm{~cm}$ long, $0.7-3 \mathrm{~cm}$ wide, oblique to cuneate, acuminate. Racemes 20-45 cm long, with 20-40 flowers, in whorls of 2-5 or scattered; peduncles 7-10 cm long; pedicels 4-8 $\mathrm{mm}$ long, densely tomentose; bracts persistent, ovate, 8-14 mm long, 3-8 $\mathrm{mm}$ wide. Flowers $1.6-$ $1.8 \mathrm{~cm}$ long; calyx 7-9 $\mathrm{mm}$ long, 5-8 $\mathrm{mm}$ wide at the limb, lobes $2-4 \mathrm{~mm}$ long, as long as or shorter than tube; wing and keel petals asymmetrically oblong-rhombic; ovary densely tomentose; ovules 10-13. Pods arcuate, divergent, 4.5-6.5 cm long, 0.4-0.5 cm wide, densely tomentose. Seeds 5-10, brown, reniform without a rostrum, 3.5-4 mm long, $2 \mathrm{~mm}$ wide.

Distribution and ecology (Fig. 1). Known only from northwestern California, Humboldt and Siskiyou cos., along ridgetops, 150-1500 m; flowering May-June.

Specimens examined. U.S.A. California: Humboldt Co., ca. $12 \mathrm{mi}$. SW of Orleans, Bee Mt., Quick 5942 (CAS, COLO, TEX); $11 \mathrm{mi}$. from Orleans on Bar Shanty Road, 6 July 1956, Tillett 620 (POM); E of Korbel, Bald Mt., on trail to Blohn's cabin, June 1951,
Vollmer \& Beane 146 (CAS, POM, WTU); near Orleans, 19 May 1931, Wieslander 7 (RM, UC). Siskiyou Co., $11 \mathrm{mi}$. N of Somes Bar, shady forest near Camp Three, 22 June 1954, Hitchcock 20223 (NY, WTU); $9.5 \mathrm{mi}$. N of Klamath River, Cedar Camp Road, 11 July 1950 Hoffman 3643 (UC); Prospect Hill, 1220 m, 18 July 1950, Tracy 19220 (UC); Prospect Hill, 20 July 1950, Tracy 19213 (POM, UC, WTU); near State Creek, 12 June 1928, Wieslander 129 (JEPS). County unknown, coast of California, Vasey $1876(\mathrm{GH})$.

Thermopsis robusta is a localized, robust endemic of northwestern California. Because of its habit, large leaflets, and densely pilosulous vestiture it is superficially similar to T. macrophylla. Both Larisey (1940) and Isely (1981) included T. robusta within their concept of T. macrophylla var. macrophylla. We believe it is more closely related to $T$. gracilis, to judge from its divergent pods and distribution.

10. Thermopsis villosa (Walter) Fernald \& B. G. Schubert, Rhodora 50: 201. 1948. Sophora villosa Walter, Fl. Carol. 134. 1788. TYPE: U.S.A. North Carolina: without definite locality or date, Walter s.n. (holotype, BM not seen). Typification of this plant is thoroughly discussed by Fernald \& Schubert in their transfer of the species from Sophora to Thermopsis.

Thermopsis caroliniana M. Curtis, Amer. J. Sci. 44: 80. 1843. TYPE: U.S.A. North Carolina: Haywood Co., "in sylvis montanis," M. A. Curtis 1839 (holotype, $\mathrm{GH}$; possible isotypes, $\mathrm{PH}, \mathrm{NY}$ ).

Plants delicate, 6-18 dm tall, glabrate (densely villous inflorescences); stems thick, erect, solitary or clustered, few-branched, arising from a woody rootstock; branches spreading at $45-60^{\circ}$, moderately zigzagged. Leaflets elliptic, 4-9.5 cm long, $1.8-4.4 \mathrm{~cm}$ wide, acute to obtuse, glabrate above, sparsely villous below, lateral veins $6-8$ pairs, conspicuously net-veined beneath; petioles $2-5(-6) \mathrm{cm}$ long; stipules persistent, elliptic to ovate, 1.5-4.5 cm long, 0.9 to $2.4 \mathrm{~cm}$ wide, oblique to cuneate, acute to obtuse. Racemes $15-50 \mathrm{~cm}$ long, with 10-50 flowers, scattered or in whorls of 2-3; peduncles 6-13 cm long; pedicels $2-3 \mathrm{~mm}$ long, densely villous; bracts deciduous, widely ovate to widely obovate, 5-7 $\mathrm{mm}$ long, 5-6(-8) $\mathrm{mm}$ wide. Flowers 1.7-1.9 cm long; calyx 7-8 mm long, 5$6.5 \mathrm{~mm}$ wide at the limb, lobes $2-3 \mathrm{~mm}$ long, much shorter than tube; wing and keel petals asymmetrically oblong-rhombic; ovary velutinous; ovules 12-16. Pods straight to slightly arcuate, erect, 4$5.5 \mathrm{~cm}$ long, $0.4-0.6 \mathrm{~cm}$ wide, densely tomentose to villous. Seeds 7-12, olive brown, elliptic with a 


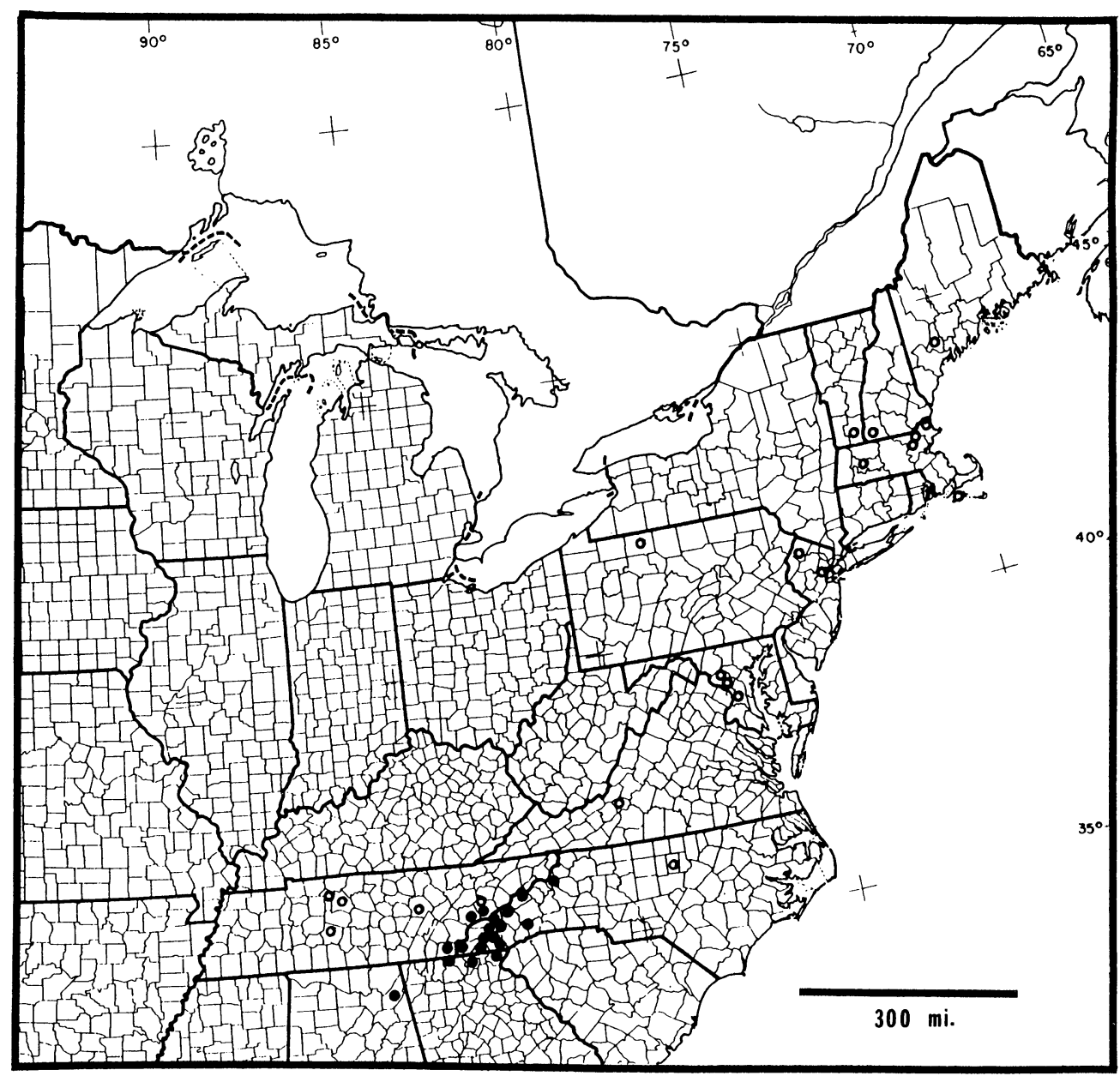

FIGURE 8. Distribution of Thermopsis villosa: collections thought to be native (closed circles); collections thought to be introduced or cultivated (open circles).

rostrum, 3-3.5 mm long, 1.8-2 mm wide. Chromosome number, $2 n=18$.

Distribution and ecology (Fig. 8). Native to eastern Tennessee, western North Carolina, northeastern Alabama, northern Georgia, and closely adjacent South Carolina, cultivated northward to Maine, scattered localized populations in open areas of deciduous oak woodlands, mostly 1000$1600 \mathrm{~m}$; flowering May-June(-July).

Representative specimens examined. U.S.A. Alabama: DeKalb Co., 6 mi. N of Dawson, 2 July 1943, Harper 3941 (F, GH, MO). Georgia: Fannin Co., near Three Forks Mountain, 28 June 1983, Coile et al. 3736 (RM), 23 July 1909, Smith 2475 (F). Rabun Co., Tallulah River, Small 1893 (F, GH, MO, NY, PH, UC, US). Union Co., Brasstown Bald Mt., 15 July 1908, Howell 393 (US). Maine: Hancock Co., Reef Point Gardens, Spaulding $582(\mathrm{GH})$. Maryland: Prince Georges Co., Hermann 18409 (RM). Massachusetts: Hampshire Co.,
Northampton, railroad right-of-way, Ahles 78850 (TENN). Middlesex Co., Framingham, Pike exit to Massachusetts Hwy. 9, 27 June 1975, Ahles 80370 (NEBC); Wilmington, W side of Interstate Hwy. 93, 22 June 1986, Boufford \& Wood 23650 (CAS, NEBC, MO, PH). New Hampshire: Cheshire Co., Boufford 6134 (MO). New Jersey: Sussex Co., Edwards 1971 (NCU). Union Co., Moldenke et al. 30109 (ARIZ, LL). North Carolina: Avery Co., 0.5 mi. N of Cranberry on U.S. Hwy. 19E, 17 June 1958, Ahles \& Duke 43574 (NCU). Cherokee Co., Notlely River near North Carolina Hwy. 60, 6 June 1953, Radford \& Haesloop 7187 a (NCU); Rugel 1842 (NY). Clay Co., base of Doe Knob, Buck Creek, 24 July 1951, Godfrey 51485 (TENN, US); NE of Chunky Gal Mt., along Buck Creek Road, 26 June 1970, Leonard et al. 3314 (NCU). Haywood Co., $1.6 \mathrm{mi}$. N of Cove Creek, 5 June 1958, Ahles \& Duke 42242 (NCU). Henderson Co., ca. 1 mi. N of Lake Logan, 12 June 1964, Wilbur 7142 (GH, UC). Jackson Co., near Soco Falls, 6 July 1940, Hood 109 (MO); Soco Gap, ca. 3 mi. W of U.S. Hwy. 19, 1 July 1954, Sargent 6851 (POM, RM, WTU). Macon Co., near Highlands, Biltmore Herbarium $1332 b$ (F, GH, MO, NCU, NY, US); 3 mi. SE of Sassafras 
Gap, 18 June 1969, Leonard \& Russ 2512 (COLO, NCU, POM, TENN, UC, WTU); $6.7 \mathrm{mi}$. W of Wayah Valley Ranch, Arrowood Glade, 29 June 1970, Turner 6072 (F, GH, NY, RM, TEX, WTU). Madison Co., Ahles $\&$ Duke 46380 (NCU, NY). Swain Co., along stream, 12 June 1982, Churchill 82698 (RM); 1.3 mi. from North Carolina Hwy. 28 on Mica Knob Road, 6 June 1956, Bell 3200 (GH, NCU). Transylvania Co., U.S. Hwy. 276 near Pink Beds, 23 Sep. 1957, Freeman 57819 (NCU); along motor road in Pink Beds, Ripper 307 (RM). Pennsylvania: McKean Co., Fogg \& Wherry 9818 (PH). Tennessee: Blount Co., Cades Cove, near Crib Gap, Hoss 1954 (TENN). Cumberland Co., Adams 1962 (NCU, TENN, US). Davidson Co., NW Nashville, at intersection of Marrowbone and Eaton's Creek Roads, 17 June 1968, Kral 31489 (NCU, TENN). Maury Co., just $\mathrm{S}$ of and above Rockdale on U.S. Hwy. 43, 26 June 1970, Kral 39741 (GH, MO, NY); Harpeth hills near Nashville, Gattinger 1879 (GH, MO, NY, US). Polk Co., ca. $1.5 \mathrm{~km} \mathrm{SE}$ of summit of Big Frog Mt., 14 July 1983, Z. E. \& J. B. Murrell 389 (TENN). Vermont: Windham Co., Charette 3345 (MO), and 3349 (NEBC). Virginia: Roanoke Co., Uttal 6228 (NCU).

Thermopsis villosa is a distinctive, stiffly erect species of the southern Appalachian ridges and upper valleys. Czefranova (1970) treated it (as $T$. caroliniana) as the only member of series Carolinianae. It is superficially similar to the Californian T. macrophylla, as noted by Gray (1848a), in having densely villous inflorescences and closely compacted erect pods but differs markedly from that species in its much more slender, strict habit and glabrate foliage.

Sporadic, locally naturalized populations of this taxon occur from Virginia, northeastward to Maine. Fernald (1950) did not account for T. villosa in his treatment of Thermopsis for the northeastern United States, nor did he comment on the clearly naturalized populations of this species outside of its natural distribution (Fig. 8).

The species was taken into cultivation early on. Gray (1848a) stated "I raised the plant in the Cambridge Botanic Garden (where it is perfectly hardy) from seeds . . . communicated by Mr. Buckley." No doubt the species is still retained in the occasional garden or has persisted in gardens long vacated. One collection is known from Hawaii (Oahu, "Mauka of Kawaiiki ditch intake," 30 Apr. 1939, Degener 17363, GH). We also believe that the numerous collections near Nashville, first made by Gattinger in the Harpeth hills in 1875 (MO, TENN, US), may also be locally naturalized populations.

\section{LITERATURE Cited}

Abrams, L. 1944. Fabaceae. Pp. 480-627 in An Illustrated Flora of the Pacific States, Washington, Oregon, and California, Vol. 2. Stanford Univ. Press, Stanford, California.
Alston, R. E. \& B. L. Turner. 1963. Natural hybridization among four species of Baptisia (Leguminosae). Amer. J. Bot. 50: 159-173.

Balandrin, M. F., E. F. Robbins \& A. D. Kinghorn. 1982. Alkaloid distribution in some species of the Papilionaceous tribes Thermopsideae and Genisteae. Biochem. Syst. \& Ecol. 10(4): 307-311.

Bisby, F. A. 1981. Genisteae (Adans.) Benth. Pp. 4094.25 in R. M. Polhill \& P. H. Raven (editors), Advances in Legume Systematics. Royal Botanic Gardens, Kew.

Brewer, W. H. \& S. Watson. 1880. Polypetalae. In Botany of California, Vol. 1. Welch, Bigelow, Cambridge, Massachusetts.

Brown, R. 1811. P. 3 in W. T. Aiton (editor), Hortus Kewensis, ed. 2, Vol. 3. Longman, Hurst, Rees, Orme \& Brown, London.

Chen, C. J., X. Y. Zhu \& Y. M. Yuan. 1992. Cytological studies on the tribe Thermopsideae (Fabaceae) I. Report on karyotypes of eleven species of four genera. Cathaya 4: 103-116.

Cranmer, M. F. \& B. L. Turner. 1967. Systematic significance of lupine alkaloids with particular reference to Baptisia (Leguminosae). Evolution 2]: 508-517.

Cristofolini, G. 1987. Serological relationships among Sophoreae, Thermopsideae, and Genisteae (Fabaceae). Bot. J. Linn. Soc. 94: 421-432.

— \& L. Feoli-Chiapella. 1984. Origin and diversification of the Genisteae. Webbia 38: 105-122.

Czefranova, Z. 1970. Series novae generis Thermopsis R. Br. Novitates Systematicae Plantarum 7: 213216.

Dement, W. A. \& T. J. Mabry. 1975. Biological implications of flavonoid chemistry in Baptisia and Thermopsis. Biochem. Syst. \& Ecol. 3: 91-94.

Faugeras, C. \& R. Paris. 1968. Chemiotaxinomie des Papilionacées-Genistées. Bull. Soc. Bot. France 1965: 75-102.

Federov, A. A. (editor). 1969. Chromosome Numbers of Flowering Plants. Acad. Sci. USSR, Moscow.

Fernald, M. L. 1950. Gray's Manual, 8th ed. American Book Company, New York.

Gillett, J. M. 1975. In: A. Löve (editor), IOPB Chromosome Number Reports L. Taxon 24: 671-678.

Graustein, J. E. 1967. Thomas Nuttall, Naturalist, Explorations in America, 1808-1841. Harvard Univ. Press, Cambridge.

GRAY, A. 1848a. Chloris Boreali-Americana. Mem. Amer. Acad. Arts n.s. 3(1): 1-56.

- 1848b. A Manual of the Botany of the Northern United States. James Monroe, Boston.

Greuter, W., ET AL. 1988. International Code of Botanical Nomenclature. Regnum Veg. 118.

HarboRNE, J. B. 1969. Chemosystematics of the Leguminosae. Flavonoid and isoflavonoid patterns in the tribe Genisteae. Phytochemistry 8: 144.9-1456.

Howell, J. T. 1957. The Santa Ynez Thermopsis. Leafl. W. Bot. 7(6): 158-159.

ISELY, D. 1978. New varieties and combinations in Lotus, Baptisia, Thermopsis, and Sophora (Leguminosae). Brittonia 30: 4.66-4.72.

- 1981. Leguminosae of the United States, III. Subfamily Papilionoideae: Tribes Sophoreae, Podalyrieae, and Loteae. Mem. New York Bot. Gard. 25(3): $1-264$

LARISEY, M. M. 1940. A revision of the North American 
species of the genus Thermopsis. Ann. Missouri Bot. Gard. 27: 245-258.

LEDINGHAM, G. F. 1957. Chromosome numbers of some Saskatchewan Leguminosae with particular reference to Astragalus and Oxytropis. Canad. J. Bot. 35: 657-666.

LINK, H. F. 1821. Icones Plantarum Selectarum. Published by the author, Berlin.

LinNaEus, C. 1753. Species Plantarum, ed. 1. Holmiae [Stockholm], (impensis Laurentii Salvii).

Löve, A. \& D. Löve. 1982. In: A. Löve (editor), IOPB Chromosome Number Reports LXXV. Taxon 31: 342-368.

MEsicEK, J. \& J. SoJAK. 1969. Chromosome counts of some Mongolian plants. Folia Geobot. Phytotax. 4: 55-86.

NutTall, T. 1818. The Genera of North American Plants. Printed for the author by D. Heart, Philadelphia.

Polmill, R. M. 1976. Genisteae (Adans.) Benth. and related tribes (Leguminosae). Pp. 143-368 in V. H. Heywood (editor), Botanical Systematics, Vol. 1. Academic Press, New York.

Probatova, N. S. \& A. P. Sokolovskaya. 1981. Kariologicheskoe issledovanie sosudistykh rastenij ostrovov Dal'nevostocnogo gosudarstvennogo morskogo sapovednika. Sb. Cvetkaye Rastenija Ostrovov Dalnevostochnogo Morskogo Sapovednika. Pp. 92114.

Radford, A. E., H. E. Ahles \& C. R. Bell. 1968. Manual of the Vascular Flora of the Carolinas. Univ. North Carolina Press, Chapel Hill, North Carolina.

Rafinesque, C. S. 1819. J. Phys. Chim. Hist. Nat. Arts. 89: 259.

Salatino, A. \& O. R. Gottlieb. 1980. Quinolizidine alkaloids as systematic markers of the Papilionoideae. Biochem. Syst. \& Ecol. 8: 133-147.

$\&$ 1983. Chemogeographical evolution of quinolizidines in Papilionoideae. Pl. Syst. Evol. 143: 167-174.
Shishkin, B. K. 1945. Thermopsis. Pp. 30-36 in V. L. Komarov (editor), Flora of the USSR, Vol. 11. [English translation.] Israel Program for Scientific Translation. Jerusalem. 1971.

ST. JoHN, H. 1941. Notes on North American Thermopsis. Torreya 41: 112-115.

TAYLOR, R. L. 1967. In: A. Löve (editor), IOPB Chromosome Number Reports XIII. Taxon 16: 445-461.

Torrey, J. 1857. Explorations and surveys for a railroad. Pacific Railroad Rep. 4: 81.

- 1859. Botany of the boundary. In: W. H. Emory (editor), Rep. U.S. Mex. Bound. Surv., Vol. 2, pt. l. A.O.P. Nicholson, Printer, Washington.

\& A. Gray. 1840. A Flora of North America. Wiley \& Putnam, New York.

Turner, B. L. 1967. Plant chemosystematics and phylogeny. Pure Appl. Chem. 14: 189-213.

1 1981. Thermopsideae. Pp. 403-407 in R. M. Polhill \& P. H. Raven (editors), Advances in Legume Systematics. Royal Botanic Gardens, Kew.

1982. Review of: D. Isely, Leguminosae of the United States. III. Subfamily Papilionoideae: Tribes Sophoreae, Podalyrieae, Loteae. Syst. Bot. 7(3): 350-352.

WILBUR, R. L. 1963. The Leguminous plants of North Carolina. Technical Bulletin No. 151. North Carolina Agricultural Experiment Station. Raleigh, North Carolina.

Willdenow, C. L. 1799. Species Plantarum. Berlin (impensis G. C. Nauk).

Yeh, M. S., H. Yuasa \& F. MaeKawa. 1986. Chromosome numbers in the Leguminosae. Sci. Rep. Res. Inst. Evol. Biol. 3: 57-71.

Zhukova, P. G. 1967. Karyology of some plants, cultivated in the Arctic-Alpine Botanical Garden. Pp. 139-149 in N. A. Arorin (editor), Plantarum Zonam Polarem Transportatio. II. Leningrad. 